\section{GREQAM}

Groupement de Recherche en Economie Quantitative d'Aix-Marseille - UMR-CNRS 6579

Ecole des Hautes études en Sciences Sociales Universités d'Aix-Marseille II et III
Document de Travail $\mathbf{n}^{\circ} 2011-20$

\title{
Political versus Economic Institutions in the Growth Process
}

\author{
Emmanuel Flachaire \\ Cecilia García- Peñalosa \\ Maty Konte
}

April 2011 


\title{
Political versus Economic Institutions in the Growth Process*
}

\author{
Emmanuel Flachaire \\ Aix-Marseille University ${ }^{\dagger}$
}

\author{
Cecilia García-Peñalosa \\ Aix-Marseille University ${ }^{\ddagger}$
}

\author{
Maty Konte \\ Aix-Marseille University ${ }^{\S}$
}

April 2011

\begin{abstract}
After a decade of research on the relationship between institutions and growth, scholars in this field seem to be divided. Economic institutions perform well in growth regressions and a body of literature argues that this supports the key importance of institutions for development. Other authors maintain that the type of constraints that the recent theoretical literature describes are the more stable political institutions, and these have been found to play no role in empirical growth analyses. In this paper we re-examine the role that institutions play in the growth process using cross-section and panel data for both developed and developing economies over the period 1970-2000. Our results indicate that the data is best described by an econometric model with two growth regimes. Political institutions are the key determinant of which growth regime an economy belongs to, while economic institutions have a direct impact on growth rates within each regime. These findings support the hierarchy of institutions hypothesis, whereby political institutions set the stage in which economic institutions and policies operate.
\end{abstract}

JEL Classification: O43 - O47

Key words: growth, institutions, cross-country regressions, mixture regressions

\footnotetext{
*Ackowledgements: We would like to thank Ann Owen for providing some of the data used in this paper, as well as seminar participants at Greqam. García-Peñalosa is a CNRS researcher at Greqam and her work was partly supported by the French National Research Agency Grant ANR-08-BLAN-0245-01.

†GREQAM, Centre de la Vieille Charité, 2 rue de la Charité, 13002 Marseille - Email : emmanuel.flachaire@univ-cezanne.fr

${ }^{\ddagger}$ GREQAM, Centre de la Vieille Charité, 2 rue de la Charité, 13002 Marseille - Email : cecilia.garciapenalosa@univmed.fr

${ }^{\S}$ GREQAM, Centre de la Vieille Charité, 2 rue de la Charité, 13002 Marseille - Email : maty.konte@etu.univcezanne.fr
} 


\section{Introduction}

Over the last decade a heated debate has taken place over the role of institutions for economic growth. Although simple correlations indicate that growth and institutional quality are closely related, there is no consensus about the exact way in which these two variables interact. On the one hand, there are multiple measures of institutions, raising the question of which ones matter and which do not. On the other, empirical evidence has tended to show that political institutions, which the theory argues are crucial, seem to play no role in the growth process while economic institutions are robust covariates in growth equations yet are seen as poor measures of true institutional setups. In this paper we reexamine the impact of institutions in the growth process, and ask whether the role that political institutions play in the growth process differs from that of economic institutions. ${ }^{1}$

The motivation for our approach is the hierarchy of institutions hypothesis, proposed by Acemoglu et al. (2005), which argues that political institutions 'set the stage' in which economic institutions can be devised and economic policies implemented. As such, their role is indirect and may operate either through their impact on the economic institutions and policies that a country chooses or through the effect that those have on growth. While there is some evidence for the former, ${ }^{2}$ little work has been done on the latter. We thus focus on the second effect, and maintain that the marginal effect on output growth of, say, an increase in physical capital differs across countries and depends on the institutional framework of the economy.

To test this hypothesis we follow recent work which emphasizes the existence of different growth regimes ${ }^{3}$ and argue that, although political institutions do not have a direct effect on growth, they are a key determinant of the growth regime in which a country operates. We use a finite mixture of regression models, a semiparametric method for modeling unobserved heterogeneity in the population. This approach allows us to relax the hypothesis of one growth model and to assume that there may exist several growth paths, that is, different groups such that the growth determinants have different marginal effects across groups. In contrast to other approaches that divide the data into groups, mixture regressions allow the data to determine both the number of groups and the variables that determine group membership. Once these have been identified, a particular country is endogenously allocated to a group, so that we do not require to impose ex ante either to which group a country belongs to nor which are the

\footnotetext{
${ }^{1}$ See Knack and Keefer (1995), Hall and Jones (1999), Acemoglu et al. (2001), Glaeser et al. (2004), and Glaeser et al. (2007).

${ }^{2}$ See, for example, Persson (2004) and Eicher and Leukert (2009).

${ }^{3}$ See Owen et al. (2009), Vaio and Enflo (2011) and Bos et al. (2010).
} 
relevant determinants of group membership, implying a much greater flexibility and better fit of the data than earlier work on parameter heterogeneity.

We estimate mixture regressions on a sample of developed and developing countries over the period 1970-2000, performing estimations on both the cross-section and on a panel of 5year averages. Our results indicate that the data is best described by a two-regime model, with roughly a third of countries in the high-growth group and the rest in a group with much lower average growth but highly dispersed growth rates. Political and economic institutions play very different roles. The former are, together with latitude, the key determinant of regime membership, while economic institutions are important in determining growth rates within each of the two regimes. The findings that political institutions determine regime membership are robust to the use of different measures of institutions, the inclusion of other variables such as OECD or regional dummies, and the division of our sample into two subperiods.

The paper contributes to the literature on the relationship between growth and institutions, dating back to the work of North (see North 1981) and recently spurred by Knack and Keefer (1995), Hall and Jones (1999) and Acemoglu et al. (2001). ${ }^{4}$ More specifically, it seeks to understand why it has been so difficult to identify an effect of political institutions despite a large theoretical literature indicating their importance for development. Evidence on the role of political institutions is provided by Persson and Tabellini (2006) who argue that the difficulty in identifying the impact of political regimes from within-country variations is that democracy is too broad a concept. They focus on three specific situations in which democratic reform impacts growth: the correlation between democratizations and economic liberalizations, instances where democratic institutions influence fiscal and trade policies, and allowing for 'expected political reforms' that anticipate actual reforms. In all these cases they find a stronger growth effect of democracy than is obtained in more standard growth regressions. Their approach is hence complementary to ours, as it focuses on more refined concepts of institutions.

Eicher and Leukert (2009) also find support for the hierarchy of institutions hypothesis when they use political institutions as an instrument for economic institutions which in turn have a significant effect on output levels. Moreover, when they divide their sample into OECD and non-OECD countries they find that the impact of these institutions is quantitatively more important in the latter than in the former group of economies. Both Persson and Tabellini (2008) and Nannicini and Ricciuti (2010) have allowed for parameter heterogeneity when examining the impact of transitions out of democracy into autocracy on growth rates. Persson and Tabellini

\footnotetext{
${ }^{4}$ See also Acemoglu et al. (2002), Easterly and Levine (2003), Dollar and Kraay (2003), Glaeser et al. (2004), Acemoglu et al. (2005), and Glaeser et al. (2007).
} 
(2008) use differences-in-differences regressions and provide evidence of a negative effect on growth of leaving democracy. In the same spirit, Nannicini and Ricciuti (2010) have used the synthetic control method and find that transitions into autocracy has different effects on growth across countries, with the effect being positive, negative or insignificant for different groups.

The paper is also related to the extensive literature on growth regimes, starting with Durlauf and Johnson (1995). ${ }^{5}$ Some recent papers have proposed the use of mixture regressions models to identify different growth regimes. Vaio and Enflo (2011) use historical data to identify the role of trade openness, while Bos et al. (2010) examine whether, in a world with different growth regimes, countries change regime over time. Neither of these analyses considers the role of institutions. Owen et al. (2009) consider the possibility that institutions affect group membership, and some of our results will revisit their empirical analysis. Compared to the existing literature, our main contribution is to allow for a more general model of the relationship between institutions and growth. As we will see, the results provide new empirical insights on the role played by different types of institutions in the growth process, which support the hierarchy of institutions hypothesis.

The paper is organized as follows. Section 2 describes the data, focusing on the measurement of institutions and the correlation between political and economic institutions. In section 3 we use standard regressions methods all of which indicate that although economic institutions have a positive and significant effect on growth, political institutions play no role. We then move onto the central analysis of the paper, estimating mixture regression models of both a cross-section and panel data, and performing a number of robustness analysis. Section 5 concludes.

\section{Data description and the measurement of institutions}

Most of the data we use has been extensively used by the empirical literature on the determinants of growth rates. The dependent variable is the average annual growth rate of real per capita GDP (growth), and the core covariates are initial GDP per capita $\left(\operatorname{gdp}_{0}\right)$, the average annual population growth rate (pop), the average investment to output ratio (inv) and initial years of schooling of the labor force (educ $c_{0}$ ). Our estimations are based on the standard growth equation which, following Mankiw et al. (1992), we specify as

$$
\begin{aligned}
\text { growth }=\delta_{0} & +\delta_{1} \log \left(\text { gdp }_{0}\right)+\delta_{2} \log (\text { pop }+0.05)+\delta_{3} \log (\text { inv })+\delta_{4} \log \left(\text { educ }_{0}\right) \\
& +\delta_{5} \text { dem }+\delta_{6} \text { eco }+\delta_{7} \text { lat }+\varepsilon
\end{aligned}
$$

\footnotetext{
${ }^{5}$ See also Brock and Durlauf (2001) and Eicher et al. (2007), amongst others.
} 
where the term $\log ($ pop +0.05$)$ captures the effect of population growth, depreciation and technological progress. To these core covariates we have added three potential determinants of growth: political institutions (dem), economic institutions (eco), and the geographical latitude of the country (lat).

We use two data sets, a cross-section and a panel, both of which cover the period 1970-2000. The panel data was provided by Ann Owen and was used in Owen et al. (2009). It comprises 74 developed and developing countries and averages growth rates and other variables over 5year periods, yielding (at best) six observations per country and totalling 406 observations. Our cross-section data set includes 73 countries, the same as for the panel analysis except for Guinea-Bissau for which we have no data on education at the beginning of the period.

Table 1 presents descriptive statistics and the data sources for both the cross-section and the panel. Obviously, the descriptive statistics for the panel are similar to those reported in Table 1 of Owen et al. (2009), except for our measures of institutions which differ from theirs. Owen et al. use as measures of economic and political institutions 'law and order' and 'democracy' obtained from the International Country Risk Guide (ICRG), both of which have been widely used in the literature on cross-country growth differences, starting with Knack and Keefer (1995) and Mauro (1995). These measures have been criticized by Glaeser et al. (2004) as they tend to reflect outcomes rather than political constraints. A more satisfactory variable is that provided by Polity IV, and constructed by political scientists, which aims directly at measuring political constraints. From our perspective, the ICRG variables also have the drawback that they start only in the mid 1980s, i.e. half-way through our period of analysis. This is not a problem for Owen et al. (2009) since they focus on the role of institutions as determinants of growth regimes and hence use only one time-invariant observation per country. In contrast, we will allow institutions to appear both as determinants of the regime and as standard covariates in the panel analysis, hence requiring a time dimension. We therefore use Polity IV and Fraser Institute indices, both of which are available for the entire period that we consider. ${ }^{6}$

Defining institutions is already a difficult task, measuring them even more so. In his seminal work, Douglas North defined institutions as the set of rules and norms that constrain the behavior of economic actors (North 1981, 1990). Measuring these constraints is not straightforward, particularly because there is often a substantial difference between formal institutions and the de facto constraints that agents face. The recent literature has hence coined two different concepts - those of political institutions and economic institutions- that initially aimed at capturing the

\footnotetext{
${ }^{6}$ For further discussion of the measurement of institutions see Haan (2003) and Glaeser et al. (2004).
} 
gap between formal and de facto constraints. We measure economic institutions by the index of Economic Freedom of the World (EFW) from the Fraser Institute. Economic freedom measures the extent to which property rights are protected and the freedom that individuals have to engage in voluntary transactions. This measure takes into account the respect of personal choices, the voluntary exchange coordinated by markets, freedom to enter and compete in markets, and protection of persons and their property from aggression by others. The index is an unweighted average of 5 elements: the size of the government in the economy, the legal structure, security of property rights, the access to sound money, the freedom to trade internationally, and the regulation of credit, labor and business. The country with the lowest value in our sample is Guinea Bissau (3.69) and the one with the largest is Singapore (7.79). Our main measure of political institutions is the degree of democracy obtained from Polity IV. This measure takes into account the competitiveness of executive recruitment, the openness of executive recruitment, the constraints on the executive, and the competitiveness of political participation. It ranges between 0 and 10, with a value of 0 denoting an autocratic government and a value of 10 full democracy. In our analysis below, we will allow institutions to play different roles, as they can have a direct impact on the growth rate or affect the environment in which growth occurs. Hence we define as dem 5 and eco5 the 5-year averages of our measures of political and economic institutions, respectively, and as $\operatorname{dem}_{30}$ and $\mathrm{eco}_{30}$ the averages over the entire period.

The correlation matrix in Table 2 presents some well-established facts. First, the two measures of institutions are only moderately correlated (see Glaeser et al. 2004). Second, the correlation between growth and institutions is much stronger for the cross-section than for the panel, with the correlation with economic institutions being 0.44 in the former and 0.29 in the latter. Also, the correlation is stronger in the case of economic institutions than political ones, which exhibit a correlation with growth of 0.22 in cross-section but of only 0.08 in the panel. Lastly, democracy covaries with both education and latitude, raising the question of to what extent these three variables have independent explanatory power in growth regressions.

To further understand the differences between our two institutional variables, Table 3 decomposes the data into their between-country and within-country components. We can see that the two variables have roughly the same mean but the dispersion of $\mathrm{dem}_{5}$ is substantially greater than that of $\mathrm{eCO}_{5}$. The within country component is smaller than the between-country one in both cases, but the difference between the two is much larger for dem $_{5}$, indicating the greater relative stability of this measure. Figure 1 gives some country example of the evolution of the two variables over time, with democracy being depicted by the continuous line and economic 
institutions by the dashed one. The figure indicates substantial variations over time as well as very different country patterns. In some cases, such as Botswana, the two institutions are virtually identical, but for most countries this is not the case. There are many instances in which there is a gap between the two variables, but the time trend is the same for both (France, Tunisia, Venezuela). The size of the gap varies, being small in France and large in Tunisia, where economic institutions are much better than political ones. In the US and in China political institutions have remained stable while economic ones have improved over time, but the difference between the two countries is that in the former eco 5 has been catching up with dem $_{5}$, while in the latter the two measures have diverged over time. The overall tendency has been for an improvement in institutional quality but there are exceptions, with Brazil, Peru, Sri Lanka, Venezuela and Zimbabwe exhibiting a deterioration of one or the other measure.

\section{$3 \quad$ Standard regression models}

The data discussed above indicates that our two measures of institutions are not only conceptually different, but also diverse in terms of their evolution over time and the degree of correlation with economic performance, raising the question of whether their role in the growth process is also different. In order to address this question, we start by considering the standard approaches that have been used to examine the determinants of growth rates, and ask to what extent these have been able to satisfactorily identify the impact of institutions. We first consider cross-section data, using Ordinary Least Squares (OLS) and Instrumental Variables (IV) estimation methods. Then, we consider panel data, using Fixed-Effect (FE) and Random-Effects (RE) models with and without IV estimation methods, and show that a similar pattern emerges from all the estimated models.

\subsection{Cross-section}

The first column in Table 4 presents OLS estimation results. The coefficient on initial GDP $\left.\left(g_{0}\right)_{0}\right)$ is significant and negative in line with the convergence hypothesis. The coefficients on education ( educ $_{0}$ ), investment (inv) and economic institutions (eco) are all significant and have a positive impact on growth. In contrast, political institutions (dem) exhibits an insignificant coefficient, as is the case with population growth rate (pop) and latitude (lat).

The literature has extensively discussed the fact that both institutional quality and educational attainment may be determined by economic performance. To deal with the possible endogeneity of these variables, we use IV estimation with settler mortality (in logs), population 
density in 1500 (in logs) and a dummy variable for French legal origin as instruments. ${ }^{7}$ Columns 2-5 in table 4 present IV estimation results with, respectively, education, political institutions, economic institutions and the three variables together taken as endogenous. When we treat only one variable as endogenous (educ, dem or eco), we can see that the coefficient of economic institutions is always significant at the $5 \%$ level, while political institutions still have no effect on growth. Moreover, we can see that the null hypothesis of consistent OLS estimation is always rejected (Hausman test), and that the validity of the instruments is rejected when eco is endogenous (Sargan test), while the null of weak instruments is never rejected. ${ }^{8}$ The validity of the instruments when we allow for the endogeneity of institutions is an important question: this hypothesis is rejected when eco is endogenous, and "nearly" rejected with endogenous demo (in this case, the Sargan test does not reject the null at $5 \%$ but its $p$-value, equal to 0.057 , is very close to the nominal size). Furthermore, having weak instruments is problematic since it can lead to biased estimates and poor finite sample inference (see Stock et al. 2002). Our results suggest that the choice of appropriate instruments for institutions is a difficult issue, as pointed out recently in the literature (see Durlauf et al. 2005, and Pande and Udry 2006). Note that, when we consider the three variables as being simultaneously endogenous (last column) the standard errors in parenthesis increase dramatically and none of their coefficients is significantly different from zero. This lack of precision maybe due to the small number of observations in the sample together with the large number of parameters to estimate. Since our choice of instruments implies that observations are available only for countries with a colonial history, the sample size is very small -only 43 observations- and the estimation and test can suffer from small sample problems.

Our negative results on the validity and weakness of the instruments together with the small number of observations suggest that IV estimation results are not satisfactory in our crosssection analysis. It is then possible that the difficulty in identifying the effect of institutions, particularly of political institutions, is due to these problems. The usual way to increase the precision of the estimation and get more reliable results is to use more observations. Since in growth regressions we have a limited number of countries, the only option is to use panel data.

\subsection{Panel}

The first column in table 5 presents pooled OLS estimation results using our panel data set. We include time dummies in the covariates to take into account time-effects. Standard errors are

\footnotetext{
${ }^{7}$ See Acemoglu et al. (2005) for a discussion of these instruments.

${ }^{8}$ The test statistic is the first-stage $F$-test in the case of one endogenous variable. Instruments are supposed to be strong if it is greater than 10 , and weak otherwise.
} 
smaller than those of the cross-sectional OLS estimation (Table 4, column 1) and, as expected, the coefficient estimates are more precise. We can see that economic institutions still have a significant and positive coefficient, while that on political institutions remains insignificant.

However, using pooled OLS estimation does not make use of the most important advantage of using panel data. If important variables are unobserved, coefficient estimates can be significantly biased. IV estimation can be used to solve this problem of omitted variable bias but, as we saw above, it is difficult to find good instruments. Panel estimation is an alternative approach to solve this problem, using the time dimension to control for unobserved but fixed omitted variables. A frequent way of considering individual unobserved heterogeneity is to allow the intercept in model (1) to be different for every country, $\delta_{0 i}$, while the other coefficients are assumed to be the same across countries, $\delta_{1}, \ldots, \delta_{7}$. We can define $\delta_{0 i}$ including in the regression a dummy for each country (fixed-effects) or modelling it as a random coefficient drawn from a normal distribution (random-effects). The second and third columns in Table 5 present estimation results for fixedeffects and random-effect models, with time dummies in the covariates (models (ii) and (iii)). Again, we can see that economic institutions have significant and positive coefficients, while those on political institutions are not significant at the $5 \%$ level. For the fixed-effects model, the test of the null that the country fixed-effects are constant is rejected (country-effects test with $p$-value $<0.001)$, which suggests that the pooled OLS estimation is inappropriate, while the Hausman test suggests that the random-effects model is less appropriate than the fixed-effects one. In this last model, the coefficient on economic institutions is substantially larger than in our previous estimations.

The last column in Table 5 presents estimation results for fixed-effects models with the IV estimator used by Balestra and Varadharajan-Krishnakumar (1987). We use the first lags of education and institutional variables as instruments and find that the conclusions on the role of economic and political institutions remain unchanged: coefficient estimates are significant for eco, not for dem.

\subsection{Discussion}

The results using standard regression models give a consistent picture: economic institutions have positive and significant coefficients, while those on political institutions are never significant. These results support the argument put forward by Glaeser et al. (2004) that the empirical evidence does not establish a link between institutions and economic performance since measures of economic institutions do not capture the set of rules that constraint behavior and political ones play no role in the growth process. 
One possible interpretation is simply that institutions are irrelevant. An alternative is that the implicit assumptions imposed by the standard approach are too constraining and do not allow the identification of the impact of political institutions. In particular, we have been estimating regressions models in which all countries follow the same growth process. But what if they do not? In fact, both Acemoglu et al. (2005) and Persson (2004) have argued that political institutions set the stage for economic activity and the creation of economic institutions. It is hence possible that political institutions do not affect growth rates per se but rather the way in which different covariates impact growth. That is, they could be a determinant of the type of growth regime in which a country finds itself. To investigate empirically this hypothesis, we need to go beyond standard regression models. Our proposed approach is to use finite mixture of regression models.

\section{Finite-mixture models}

Finite mixture of regression models are semiparametric methods for modeling unobserved heterogeneity in the population. They allow us to relax the hypothesis of one growth model and to assume that there may exist several growth paths, that is, different groups such that the growth determinants may have different marginal effects across groups. In the regression model (1), this is equivalent to relaxing the hypothesis that the coefficients $\delta_{1}, \delta_{2}, \delta_{3}, \delta_{4}, \delta_{5}, \delta_{6}$ and $\delta_{7}$ are common to all countries. To illustrate the approach, let us consider the simple case of two groups, or two growth paths. A mixture of linear regressions assumes that an observation belonging to the first group and one belonging to the second group would not be generated by the same data-generating process. The mixture model can be written as follows:

$$
\begin{array}{llll}
\text { Group 1: } & y=x \beta_{1}+\varepsilon_{1}, & & \varepsilon_{1} \sim N\left(0, \sigma_{1}^{2}\right), \\
\text { Group 2: } & y=x \beta_{2}+\varepsilon_{2}, & & \varepsilon_{2} \sim N\left(0, \sigma_{2}^{2}\right),
\end{array}
$$

where $y$ is the dependent variable, $x$ a set of covariates, and $\varepsilon_{1}$ and $\varepsilon_{2}$ are independent and identical normally distributed error terms within each group, with variances of $\sigma_{1}^{2}$ and $\sigma_{2}^{2}$, respectively. Since the sets of coefficients $\beta_{1}$ and $\beta_{2}$ are not (necessarily) equal, covariates $x$ do not explain in the same way differences in $y$ between observations belonging to the first group and between observations belonging to the second group. Applied to our growth regression model, this mixture model assumes that countries can be classified into two groups, associated to two different growth paths, and at least one covariate does not explain identically growth discrepancies within the two groups. Note that such assumption can be taken into account in the standard regression model (1) if we include additional covariates computed as cross-products 
of the variables of interest with a dummy variable that specifies group membership. However, in this case the groups have to be defined a priori according to some prior believe of the researcher, such as the hypothesis that the convergence coefficient is different for OECD countries than for other economies. In contrast, in a finite-mixture model, group membership is not imposed but rather estimated so as to create classes that are homogeneous in terms of the relationship between $y$ and $x$. Moreover, the number of groups is not fixed but endogenously determined according to an econometric criterion or test.

A set of additional covariates, called concomitant variables, can be used to characterize group profiles. Concomitant variables play the same role as covariates in a multinomial regression model designed to explain group membership. The roles of standard covariates and of concomitant variables are different: standard covariates help to explain variations within groups, whereas concomitant variables explain variations between groups. As a result the values of the concomitant variables will determine the probability that a particular country belongs to one class or another.

A general mixture regression model can be written as follows:

$$
f(y \mid x, z, \Theta)=\sum_{k=1}^{K} \pi_{k}\left(z, \alpha_{k}\right) f_{k}\left(y \mid x ; \beta_{k}, \sigma_{k}\right),
$$

where $K$ is the number of components or groups, $\pi_{k}\left(z, \alpha_{k}\right)$ is the probability of belonging to group $k$ with a set of specific concomitant variables $z$, and $f_{k}\left(y \mid x ; \beta_{k}, \sigma_{k}\right)$ is a conditional probability distribution characterized by a set of parameter and of covariates $x$. The parameters $\alpha_{k}, \beta_{k}$ and $\sigma_{k}$ are unknown and hence estimated. If we consider $f_{k}$ as Gaussian distributions with conditional expectations equal to $E(y \mid x)=x \beta_{k}$, for $K=1$ this model reduces to (1) and for $K=2$ this model reduces to (2).

For a given number of components $K$, finite mixture models are often estimated by maximum likelihood with the EM algorithm of Dempster et al. (1977). The log-likelihood function can be highly non-linear and a global maximum can be difficult to obtain. It is then recommended to perform the estimation with many different starting values. The number of components $K$ can be selected minimizing a criterion, such as the Bayesian Information Criterion, denoted BIC and developed by Schwarz (1978), or the Akaike Information Criterion (AIC, see Sugiura 1978, and Hurvich and Tsai 1989). More specifically, the BIC is defined as

$$
\mathrm{BIC}=-2 \hat{\ell}+(\# \text { param }) \log n
$$

where $\hat{\ell}$ is the estimated value of the $\log$-likelihood and $n$ is the number of observations. ${ }^{9}$

\footnotetext{
${ }^{9}$ For more details on finite mixture models see McLachlan and Peel (2000) and Ahamada and Flachaire (2010).
} 
Mixture models then have two desirable features. First, covariates are allowed to have different marginal effects across groups. An additional feature of mixture models is the ability to evaluate the profile of the different groups, or growth paths, using concomitant variables which need not be binary, in contrast with often-used groups such as OECD-membership or regional dummies. Moreover, the resulting classification is in terms of probabilities, so that some countries will be part of a group with a high probability but others may have features that imply a more nuanced position. What the model does not allow is for a country to be in different groups at different times as the concomitant variables must be constant over time. ${ }^{10}$

It is important to note that there is nothing in the mixture regression model that prevents the same variables from appearing in both vectors $x$ and $z$. That is, a certain variable may both be a determinant of which group a country is in and of its growth rate within that group. This is particularly important when we want to consider the role of institutions since, on the one hand, the literature maintains that institutions set the context in which different factors affect growth, and on the other we have seen that in standard regression analysis economic institutions systematically appeared with significant coefficients. Allowing for institutions to play both roles implies that we need not make any ex ante decisions about how they enter the growth process but rather late the data determine this.

\subsection{Cross-section}

We start by estimating a mixture-model on our cross-section dataset. Because we have only 73 countries and a large number of parameters to estimate, the number of components and the number of concomitant variables we can use are limited. In all the models, we include $\log \left(\mathrm{gdp}_{0}\right), \log ($ pop +0.05$), \log ($ inv $)$ and $\log \left(\right.$ educ $\left._{0}\right)$ as core covariates. The variables dem, eco and lat are included as additional standard covariates and/or concomitant variables in many different ways. Since the number of observations is not large, we do not consider more than two classes, i.e. $K \leq 2$, although we will allow for a greater number of groups when we exploit the panel dimension.

Table 6 shows values of BIC (AIC in brackets) obtained from the estimation of several different finite mixture models. $Z$ is the set of concomitant variables and $X$ the set of additional standard covariates included in the model. The first column shows BIC and AIC values of finite mixture models estimated with no concomitant variables. For instance, the case $X=\{$ dem,eco,lat $\}$ and $K=1$, which corresponds to the OLS estimation made previously in the

${ }^{10}$ The question of regime migration is a complex one and has been recently addressed by Bos et al. (2010). 
standard regression models (Table 4, column 1), has a BIC equal to 260.1. The same model with $K=2$ has a smaller value of the BIC, equal to 257.4, suggesting that imposing a single growth path is not appropriate. Other columns present results for finite mixture models with concomitant variables. Using appropriate concomitant variables should help to detect endogenously the groups. We select the model with the lowest value of the BIC, which is the specification with eco and lat included as standard covariates and dem as the only concomitant variable. Compared to the standard OLS estimation, it is clear that a significant improvement is obtained with the selected finite-mixture model: the BIC moves from 260.1 to 241.7.

Table 7 presents estimation results of the selected model with cross section data. The marginal impact of most covariates is not the same within the two groups, indicating that there are two growth processes. The BIC criterion leads us to select a model with the variable eco as a covariate and dem as a concomitant variable. That is, the data indicate that both types of institutions affect growth. Their roles are nevertheless different. Political institutions are the key determinant of group membership, with the negative coefficient on dem indicating that when this variable increases, the probability of belonging to the second group decreases. ${ }^{11}$ Economic institutions are, just as in the standard analyses, a determinant of the growth rate, with better institutions increasing growth in economies with low levels of democracy but having a negative and small effect in the other group. These results suggest that economic institutions help to explain growth discrepancies within groups, while political institutions help to explain group membership.

The results for the variables other than institutions are similar to those obtained previously from standard growth regression model (see Tables 4 and 5) although some important differences appear across groups. The coefficient on initial gdp is larger (in absolute value) for group 1 in line with previous results on conditional convergence that have found convergence among certain groups of countries, such as OECD countries, but not others; see Mankiw et al. (1992). However, we will see below that this is not the case when we consider panel data. Investment in physical capital has similar coefficients while initial educational attainment seems to matter only for group 2. The Wald test of equality of the coefficients across groups does not reject the null hypothesis under which coefficients on investment are equal across groups while the null hypothesis is rejected when we consider the coefficients on education.

The use of finite mixture models with concomitant variables provide new insights on the role of institutions on growth. However, the use of a cross section dataset leads us to estimate

\footnotetext{
${ }^{11}$ We present the list of countries in each group in Table 10 for the panel analysis. The division is almost identical for the cross-section.
} 
models with many parameters and a small number of observations. We can expect to obtain more reliable results with more observations and, as in the previous section, we move onto the panel dataset.

\subsection{Panel}

When panel data is available, standard regression models and finite mixture models can both be used to take into account unobserved heterogeneity. They differ in that finite mixture models try to detect and group together observations that have similar data-generating processes, which in our case means countries with similar growth determinants. Mixture models thus consider unobserved heterogeneity at the group level, while fixed-effects and random-effects models consider unobserved heterogeneity at the individual level. Moreover, the former allow for heterogeneity in the impact of all variables, while the latter consider only heterogeneity in terms of the constant and impose the same coefficients on all other covariates.

We estimate the model in equation (3) for various values of $K$, with time dummies included in all specifications. Table 8 shows values of the BIC (AIC in brackets) statistic obtained from the estimation of many different finite mixture models on our panel dataset. $Z$ is the set of concomitant variables and $X$ the set of additional standard covariates included in the model. We provide the statistics for one, two, and three classes, although higher- $K$ models were also estimated (and always yielded higher values of the statistic). The first column shows BIC and AIC values of finite mixture models estimated with no concomitant variables. We can see that the values are always smaller for $K \neq 1$, suggesting that there is not only one growth path, as assumed in standard panel regression models. Other columns present results for finite mixture models with concomitant variables. Using appropriate concomitant variables should help to detect endogenously the groups. We report the results with dem, eco and lat as potential members of $Z$. We also considered the variable landlocked in our models; being never significant, we have not included it in any of the reported specifications.

We select the model with the lowest value of the BIC which is the one with dem, eco and lat included as standard covariates and dem and lat as concomitant variables $(\mathrm{BIC}=1834.3)$. Note that the value of the BIC for the pooled OLS estimation reported in Table 5 is equal to 1916.2 (in bold). A significant improvement is thus obtained with the selected finite-mixture model.

Table 9 presents the estimated coefficients for the selected model, and supports the main results obtained in the cross-sectional analysis. Political institutions appear as a significant concomitant while economic institutions play a role within each of the two groups. In terms of the determinants of group membership both better political institutions and a greater latitude 
(in absolute value) reduce the probability of being in group 2. When economic institutions were included as concomitant, their coefficient was insignificant across all specifications (not reported), explaining why such models were not selected.

These results contradict those of Owen et al. (2009) who find that economic and not political institutions help to classify countries into two distinct growth paths. ${ }^{12}$ In their study, they estimate finite mixture models on similar data, but they consider institutions as concomitant variables only, not as standard covariates. When we estimate their model, which is restricted to our case of no additional covariates, $X=\{-\}$, with dem, eco, lat and landlocked as concomitant variables, we reproduce their results, even though our measures of institutions are not the same. For $K=1,2,3$, we have, respectively, $\mathrm{BIC}=2038.7$, 1974.8, and 1983.1, all of them well above our chosen specification. ${ }^{13}$ Our estimation results make clear that using economic and political institutions as standard covariates provides a significant improvement (BIC=1916.2 for the pooled OLS estimation and $\mathrm{BIC}=1834.3$ for our selected mixture model). It suggests that their specification, without institutions as standard covariates, suffers from omitted variable bias and hence cannot properly identify the role played by the two types of institutions.

Turning now to the determinants of growth rates within the two groups, we can see that differences across the two groups are larger than for the cross-section. The coefficient on initial gdp is now larger for group 2, indicating that for these countries (conditional) catching up is more important than for the mature economies. A possible interpretation is that group 2 growth rates can be explained by a neoclassical growth model, while in group 1 other mechanisms such as endogenous technological change are at play. Investment in physical capital has a positive and significant coefficient for both groups, although not significant different across them, while human capital presents coefficients of opposite signs across the two groups. ${ }^{14}$ The selected model includes both political and economic institutions, as well as latitude as standard covariates. The latter two variables have a positive and significant coefficients for both groups, and the impact of eco is larger for group 2. ${ }^{15}$ This suggests that, ceteris paribus, an improvement in economic institutions would have an expected smaller effect on growth in group 1 countries than in countries belonging to group 2. Lastly, the coefficient on political institutions as standard covariates is not significant at $1 \%$ and $5 \%$, while it is significant as concomitant variable.

\footnotetext{
${ }^{12}$ They also find no role for latitude, which according to our results is an important determinant of class membership.

${ }^{13}$ Results are available upon request.

${ }^{14} \mathrm{On}$ the empirical relationship between growth and human capital see, amongst others, de la Fuente and Domenech (2001) and Temple (2001).

${ }^{15}$ This is in line with the findings of Eicher and Leukert (2009) who divide their sample between OECD and non-OECD countries and obtain that economic institutions have a greater effect on output levels in the latter.
} 
Lastly, we can analyze the composition of the groups. The probability that a specific country belongs to a given group can be computed using Bayes rule. For instance, the posterior probability that country $i$ belongs to group $k$ is equal to

$$
\hat{\pi}_{i k}=\frac{\pi_{k}\left(z_{i}, \hat{\alpha}_{k}\right) f_{k}\left(y_{i} \mid x_{i} ; \hat{\beta}_{k}, \hat{\sigma}_{k}\right)}{\sum_{k=1}^{K} \pi_{k}\left(z_{i}, \hat{\alpha}_{k}\right) f_{k}\left(y_{i} \mid x_{i} ; \hat{\beta}_{k}, \hat{\sigma}_{k}\right)}
$$

We can then use the model reported in Table 9 to compute $\hat{\pi}_{i k}$. We then allocate country $i$ to group 1 if and only if the probability of being in that group is greater than that of being in group 2. The first group includes 23 countries and the second 51 . Table 10 reports the classification of the countries with their group membership posterior probability. In general, these probabilities are close to one, yet there are some exceptions such as Poland which has a probability of only 0.56 of being in group 2. Most of the countries belonging to the first group are rich countries, although it includes Botswana and Egypt. In the second group we find middle- and low-income countries yet the classification does not exactly coincide with the ones obtained by ad hoc ex ante divisions. For example, it includes several OECD members (Chile, Ireland, Mexico, Poland, and Turkey) and the East-Asian 'tigers' (Korea, Malaysia and Singapore).

Table 11 reports the average values of growth and institutions for the two groups, as well as the within-group standard deviations. There are important differences in some variables but not in others. The average growth rate is $2.287 \%$ for the high-democracy group and only $1.425 \%$ for the low-democracy one. However the latter exhibits a much larger standard deviation (3.238 against 1.558 for the high-democracy group), not surprising given that this group includes both some of the so-called 'growth miracles' and 'growth disasters'; see Durlauf et al. (2005). Differences across groups in economic institutions are small, with average values of 6.483 and 5.459 and similar standard deviations. In contrast, group 1 exhibits an average value of our index of political institutions which is more than twice that observed for group 2 countries (8.929 and 4.247, respectively). Although the standard deviation of dem is somewhat lower for group 1 than for group 2 , it nevertheless indicates a substantial variation in the quality of political institutions even for this group.

\subsection{Robustness analysis}

In this section, we show that our results are robust to the use of IV estimation method, alternative concomitant variables and different sample periods. 


\subsubsection{IV estimation}

As we did for the standard growth regressions we consider IV estimations in order to control for the endogeneity of institutions. We are not aware of a procedure that allows to estimate mixture models using instrumental variables, and hence proceed in two steps. In the first, which we have already performed, we estimate the mixture model in order to determine group membership. Once we have determined the two groups of countries, we perform a standard IV estimation for each of these.

In order not to loose any countries, we use as instruments one-period lags of education and economic and political institutions. An alternative would have been to use settler mortality, but, as we saw earlier on, this would reduce dramatically the number of countries included. The results are reported in Table 12. Comparing them with those in Table 9 we see that, once again, economic institutions and latitude are important standard covariates for group 2, although neither of them have a significant coefficient for group 1.

\subsubsection{Alternative concomitants}

In order to test the robustness of our results we conduct a number of further estimations. The first one is to consider the role of alternative concomitant variables, namely other measures of institutions, education, and regional dummies. In all cases, a two-class model is selected (results not reported), and the resulting mixture regressions are reported in Table 13.

We start by considering different measures of institutions. Political institutions are captured by the measure of executive constraints (xconst) provided by Polity IV, a variable that has been widely used in the literature. ${ }^{16}$ Our index of economic institutions is substituted by one of its components: the regulation of credit, labor and business markets, denoted reg. The results are reported in columns (i) and (ii) of Table 13, where we see that, just as in our benchmark estimation, political institutions play a key role in determining class membership. As in Table 9 we find that economic institutions are important determinants of growth rates within groups, while executive constraints play no role, although the coefficient on the former is now significant only for group 2. A possible interpretation of this differences is that it is due to the fact that this particular index exhibits little variation amongst the countries in group 1. Once we allow for the richer composite index, that is, the variable xconst, there is greater variability in the covariate and hence its coefficient becomes significant.

The second specification adds education as a concomitant variable. There are two reasons

\footnotetext{
${ }^{16}$ This measure is used, among others, by Glaeser et al. (2004) who argue that, together with dem, it is one of the least flawed measures of institutions.
} 
why we may wish to do so. First, some of the early literature on multiple growth paths postulated that education levels were a key determinant of which group a country belonged to; see Durlauf and Johnson (1995). Second, it has been argued that education and political institutions are closely related and that higher education levels lead to good political institutions. ${ }^{17}$ Glaeser et al. (2004) show that there is a strong correlation between executive constraints and educational attainment and their results (for output levels, not growth) indicate that the coefficient on xconst looses its significance once education is included. The results in Table 13 show that although this is the case when the variables are used as standard covariates, executive constraints retain a significant coefficient as concomitant even when education is included as such. Moreover, education seems to play no role in determining class membership.

Our next robustness test consists in including regional dummies. Such dummies are often used in cross-country regressions and generally prove significant, with Latin American and African countries tending to exhibit lower growth rates than other economies. Similarly, regressions are often estimated separately for OECD countries which are argued to follow a different growth process. It is thus possible that what groups countries in classes are regional variations and that our measure of political institutions is simply serving as a proxy for regional location. Column (iii) of Table 13 reports the two-group mixture regression when we include as additional concomitants dummies for Latin American, African and OECD countries, as well as one for whether or not the country is landlocked. We can see that the coefficient on dem 30 retains its significance and is somewhat larger than in core specification (-0.388 rather than -0.299$)$, while the additional concomitants have insignificant coefficients indicating that political institutions explain group membership better than the regional dummies. ${ }^{18}$ The coefficients for the within-group regressions are very similar to our core specification (see Table 9). In contrast, latitude is now insignificant when used as concomitant, not surprising given the large number of geographical variables that we have included.

\subsubsection{Different sample periods}

One of the most striking features when we look at growth rates during the last decades of the 20 th century is that there has been a reduction in the average growth rate and an increase in its dispersion across countries; see Durlauf et al. (2005). This indicates that it is possible that either the determinants of growth rates or the way in which they impact growth have changed over our sample period. In order to address this question we divide our data into two subsamples,

\footnotetext{
${ }^{17}$ See Lipset (1960) for the seminal work and Eicher et al. (2009) for a model of the impact of education on institutions and economic performance.

${ }^{18}$ Similar results are obtained when we use xconst as our measure of political institutions.
} 
one for the earlier half (1970-1985) and another for the latter one (1985-2000) and reestimate our model.

Table 14 presents estimation results for the two periods. Because of missing observations on education, for the first period we loose four countries (Guinea Bissau, Poland, Tanzania and Uganda). Both political institutions and latitude as concomitant variables have significant coefficients in the two periods, but their relative impact seems to have change, with institutions increasing and latitude decreasing in importance as we move to the latter period. Moreover, we can see that the coefficients on economic institutions as standard covariates remain significant. As in our earlier estimations, the coefficients on dem tend to be insignificant as standard covariates, and those on latitude unstable. Investment in physical capital seems to have played a more important role in the earlier period, while the coefficients on educ obtained for the overall sample reflect the positive effect for group 1 in the earlier period and the negative one for group 2 in the later one.

\section{Discussion and conclusion}

This paper has tried to shed light on the debate concerning the role of institutions in the growth process by testing the hierarchy of institutions hypothesis, proposed by Acemoglu et al. (2005), which argues that political institutions set the stage in which economic institutions can be devised and economic policies implemented. Our hypothesis is that there exist multiple growth regimes such that the determinants of growth rates and their marginal impacts vary across regimes, and that political institutions are the key factor determining to what regime a country belongs to.

The data supports the existence of two growth regimes. The first exhibits high growth rates, averaging $2.3 \%$ per annum, while the second is characterized by lower but highly dispersed growth rates, with a mean of only $1.4 \%$ and a standard deviation of 3.2. Membership of the first regime is more likely when political institutions are strong but is unaffected by economic institutions. In fact, both groups exhibit rather similar levels of economic institutions indicating that the two types of institutions operate at a different level. When we focus on the determinants of growth rates within regimes, it is economic rather than political institutions that play a role. The coefficient on economic institutions is systematically larger for the low-democracy regime, being between twice and three times as large as for the high democracy group. The lowdemocracy regime is also characterized by a high return to human capital accumulation and a large and negative coefficient on population growth. 
Our results shed light on two open debates. The first concerns the causal impact of political institutions on growth, and our findings indicate that indeed such institutions do not have a direct impact on growth rates. The second is the debate on proximate determinants and deeper determinants of growth. ${ }^{19}$ Our results show that political institutions belong to the second class of variables, and that as such influence the environment in which growth occurs. Because they determine the value of factor returns that apply to a particular country, they are a central element in the growth process even in the absence of a significant direct effect.

The main policy implication of our analysis is that economic and political institutions can be substitutes in the growth process. Countries in which the latter are strong tend to exhibit high growth rates and a low return to improvements in economic institutions, with growth being driven by technological change and physical capital accumulation. In contrast, countries with weak political institutions have lower average growth rates but a high return to economic institutions. As a result, economies where democracy is weak but where autocratic governments improve economic institutions can attain fast growth, and the example of several East-Asian economies comes to mind. Does this mean that good political institutions are unnecessary for successful growth strategies? In the short-run the answer seems to be yes, although the question of whether this is so also in the medium term remains open. It is possible that growth strategies that are successful at early stages of development are not able to sustain growth in mature economies. If so, our results indicate that a growth regime change can only occur if there is a political regime change.

\section{References}

Acemoglu, D., S. Johnson, and J. A. Robinson (2001). The colonial origins of comparative development: An empirical investigation. American Economic Review 91, 1369-1401.

Acemoglu, D., S. Johnson, and J. A. Robinson (2002). Reversal of fortune: Geography and institutions in the making of the modern world income distribution. Quarterly Journal of Economics 117, 117.

Acemoglu, D., S. Johnson, and J. A. Robinson (2005). Institutions as the fundamental cause of long-run economic growth. In P. Agion and S. Durlauf (Eds.), Handbook of Economic Growth, Amsterdam, pp. 385-472. North Holland.

Ahamada, I. and E. Flachaire (2010). Non-Parametric Econometrics. Oxford University Press.

\footnotetext{
${ }^{19}$ See Galor (2005) for a discussion.
} 
Balestra, P. and J. Varadharajan-Krishnakumar (1987). Full information estimation of a system of simultaneous equations with error component structure. Econometric Theory 3, $223-246$.

Barro, R. and J.-W. Lee (2001). International data on educational attainment: updates and implications. Oxford Economic Papers 53, 541-63.

Bos, J., C. Economidou, M. Koetter, and J. Kolari (2010). Do all countries grow alike? Journal of Development Economics 91, 113-127.

Brock, W. and S. Durlauf (2001). Growth economics and reality. The World Bank Economic Review 15, 229-72.

de la Fuente, A. and R. Domenech (2001). Schooling data, technological diffusion and the neoclassical model. American Economic Review 91, 323-327.

Dempster, A. P., N. M. Laird, and D. B. Rubin (1977). Maximum likelihood from incomplete data via EM algorithm (with discussion). Journal of the Royal Statistical Society B 39, $1-38$.

Dollar, D. and A. Kraay (2003). Institutions, trade, and growth. Journal of Monetary Economics 50, 133-162.

Durlauf, S. and P. A. Johnson (1995). Multiple regimes and cross-country behavior. Journal of Applied Econometrics 10, 365-384.

Durlauf, S. N., P. A. Johnson, and J. R. Temple (2005). Growth econometrics. In P. Aghion and S. Durlauf (Eds.), Handbook of Economic Growth. Elsevier.

Easterly, W. and R. Levine (2003). Tropics, germs and crops: How endowments influence economic development? Journal of Monetary Economics 50, 3-39.

Eicher, T., C. García-Peñalosa, and T. V. Ypersele (2009). Education, corruption and the distribution of income. Journal of Economic Growth 14, 205-231.

Eicher, T. and A. Leukert (2009). Institutions and economic performance: Endogeneity and parameter heterogeneity. Journal of Money, Credit and Banking 41, 197-219.

Eicher, T., O. Roehn, and C. Papageorgiou (2007). Unraveling the fortunes of the fortunate: An iterative bayesian model averaging (IBMA) approach. Journal of Macroeconomics 29, $494-514$

Galor, O. (2005). From stagnation to growth: Unified growth theory. In P. Aghion and S. Durlauf (Eds.), Handbook of Economic Growth, pp. 171-293. Elsevier. 
Glaeser, E., R. La Porta, F. Lopez-de-Silanes, and A. Shleifer (2004). Do institutions cause growth? Journal of Economic Growth 9, 271-303.

Glaeser, E., G. Ponzetto, and A. Shleifer (2007). Why does democracy need education? Journal of Economic Growth 12, 77-99.

Haan, J. (2003). Economic freedom: Editor's introduction. European Journal of Political Economy 19, 395-403.

Hall, R. and C. Jones (1999). Why do some countries produce so much more output than others? Quarterly Journal of Economics 114, 83-116.

Hurvich, C. and C. Tsai (1989). Regression and time series model selection in small samples. Biometrika 76(2), 297-307.

Knack, S. and P. Keefer (1995). Institutions and economic performance: Cross-country tests using alternative measures. Economics and Politics 7, 207-227.

La Porta, R., F. Lopez-de-Silanes, A. Shleifer, and R. Vishny (1998). Law and finance. Journal of Political Economy 106, 1116-1155.

Lipset, S. (1960). Political Man: The Social Basis of Modern Politics. New York: Doubleday.

Mankiw, N., D. Romer, and D. Weil (1992). A contribution to the empirics of economic growth. Quarterly Journal of Economics 107, 407-437.

Mauro, P. (1995). Corruption and growth. Quarterly Journal of Economics 110, 681-712.

McLachlan, G. J. and D. Peel (2000). Finite Mixture Models. New York: Wiley.

Nannicini, T. and R. Ricciuti (2010). Autocratic transitions and growth. CESifo Working paper no. 2967.

North, D. (1981). Structure and Change in Economic History. New York: Norton and Co.

North, D. (1990). Institutions, Institutional Change, and Economic Performance. Cambridge: Cambridge University Press.

Owen, A. L., J. Videras, and L. Davis (2009). Do all countries follow the same growth process. Journal of Economic Growth 14, 265-286.

Pande, R. and C. Udry (2006). Institutions and development: A view from below. In R. Blundell, W. Newey, and T. Persson (Eds.), Advances in economics and econometrics: theory and applications, Ninth World Congress. Econometric Society Monographs.

Persson, T. (2004). Consequences of constitutions. Journal of the European Economic Association 2, 139-161. 
Persson, T. and G. Tabellini (2006). Democracy and development: The devil in the details. American Economic Review 96, 319-324.

Persson, T. and G. Tabellini (2008). The growth effects of democracy: Is it heterogeneous and how can it be estimated? In E. Helpman (Ed.), Institutions and Economic Performance. Harvard University Press.

Schwarz, G. (1978). Estimating the dimension of a model. Annals of Statistics 6, 461-464.

Stock, J., J. Wright, and M. Yogo (2002). A survey of weak instruments and weak identification in generalized method of moments. Journal of Business 83 Economic and Statistics 20, $518-529$.

Sugiura, N. (1978). Further analysis of the data by akaike's information criterion and the finite corrections. Communications in Statistics, Theory and Methods 7, 13-26.

Temple, J. R. (2001). Generalizations that aren't? Evidence on education and growth. European Economic Review 45, 905-918.

Vaio, G. D. and K. Enflo (2011). Did globalization drive convergence? Identifying crosscountry growth regimes in the long-run. European Economic Review, forthcoming. 


\begin{tabular}{|c|c|c|c|c|c|c|c|}
\hline Variable & Obs. & Mean & SD & Min & $\operatorname{Max}$ & Description & Data source \\
\hline \multicolumn{8}{|c|}{ Cross-section } \\
\hline growth & 73 & 1.73 & 1.80 & -3.38 & 6.11 & Average annual growth rate & PWT 6.3 \\
\hline $\log \left(\operatorname{gdp}_{0}\right)$ & 73 & 8.48 & 0.95 & 6.43 & 10.09 & Log of initial real GDP per capita & PWT 6.3 \\
\hline $\log (\mathrm{pop}+0.05)$ & 73 & 1.89 & 0.15 & 1.59 & 2.19 & $\begin{array}{l}\text { Log of population growth }+ \text { tech- } \\
\text { nology growth }+ \text { depreciation rate }\end{array}$ & PWT 6.3 \\
\hline $\log \left(\operatorname{inv}_{30}\right)$ & 73 & 3.03 & 0.49 & 1.19 & 3.91 & Log of investment rate & PWT 6.3 \\
\hline $\log \left(\right.$ educ $\left._{0}\right)$ & 73 & 1.29 & 0.74 & -1.22 & 2.33 & $\begin{array}{l}\text { Log of initial average years of edu- } \\
\text { cation of the total population aged } \\
\text { over } 15\end{array}$ & Barro and Lee (2001) \\
\hline dem & 73 & 5.52 & 3.59 & 0 & 10 & $\begin{array}{l}\text { Political institutions: degree of } \\
\text { democracy (Polity IV) }\end{array}$ & $\begin{array}{l}\text { www.systemicpeace.org, } \\
\text { Polity IV project }\end{array}$ \\
\hline eco & 73 & 5.86 & 0.89 & 4.23 & 7.79 & $\begin{array}{l}\text { Economic institutions: index of } \\
\text { Economic Freedom of the World }\end{array}$ & $\begin{array}{l}\text { www.freetheworld.com, } \\
\text { version } 2009\end{array}$ \\
\hline lat & 73 & 0.29 & 0.19 & 0.01 & 0.71 & Absolute value of latitude & La Porta et al. (1998) \\
\hline settler & 43 & 4.42 & 1.12 & 2.14 & 7.98 & Log of European settler mortality & Acemoglu et al. (2001) \\
\hline popdens & 47 & 0.23 & 1.72 & -3.83 & 4.61 & Log of population density in 1500 & Acemoglu et al. (2002) \\
\hline forigin & 73 & 0.49 & 0.50 & 0 & 1 & French legal origin & La Porta et al. (1998) \\
\hline $\begin{array}{l}\text { Panel } \\
\text { growth }\end{array}$ & 426 & 1.75 & 2.84 & -7.39 & 13.22 & $\begin{array}{l}\text { Average annual growth rate over } 5 \\
\text { year period }\end{array}$ & PWT 6.2 \\
\hline $\log \left(\operatorname{gdp}_{0}\right)$ & 426 & 7.85 & 1.49 & 4.97 & 10.48 & Log of initial real GDP per capita & PWT 6.2 \\
\hline $\log (\mathrm{pop}+0.05)$ & 426 & 1.89 & 0.16 & 1.47 & 2.31 & $\begin{array}{l}\text { Log of population growth }+ \text { tech- } \\
\text { nology growth }+ \text { depreciation rate }\end{array}$ & PWT 6.2 \\
\hline $\log (\mathrm{inv})$ & 426 & 2.76 & 0.53 & 0.62 & 3.92 & Log of investment rate & PWT 6.2 \\
\hline $\log \left(\right.$ educ $\left._{0}\right)$ & 426 & 1.55 & 0.66 & -1.34 & 2.48 & $\begin{array}{l}\text { Log of initial average years of edu- } \\
\text { cation of the total population aged } \\
\text { over } 15\end{array}$ & Barro and Lee (2001) \\
\hline $\operatorname{dem}_{5}$ & 424 & 5.67 & 4.02 & 0 & 10 & $\begin{array}{l}\text { 5-years average of the index of po- } \\
\text { litical institutions }\end{array}$ & $\begin{array}{l}\text { www.systemicpeace.org, } \\
\text { Polity IV project }\end{array}$ \\
\hline $\mathrm{ecO}_{5}$ & 408 & 5.81 & 1.14 & 2.73 & 8.65 & $\begin{array}{l}5 \text {-years average of the index of eco- } \\
\text { nomic institutions }\end{array}$ & $\begin{array}{l}\text { www.freetheworld.com, } \\
\text { version } 2009\end{array}$ \\
\hline $\operatorname{dem}_{30}$ & 74 & 5.46 & 3.59 & 0 & 10 & $\begin{array}{l}\text { 30-years average of the index of } \\
\text { political institutions }\end{array}$ & $\begin{array}{l}\text { www.systemicpeace.org, } \\
\text { Polity IV project }\end{array}$ \\
\hline $\mathrm{ecO}_{30}$ & 74 & 5.86 & 0.92 & 3.69 & 7.79 & $\begin{array}{l}\text { 30-years average of the index of } \\
\text { economic institutions }\end{array}$ & $\begin{array}{l}\text { www.freetheworld.com, } \\
\text { version } 2009\end{array}$ \\
\hline lat & 74 & 0.29 & 0.19 & 0.01 & 0.71 & Absolute value of latitude & La Porta et al. (1998) \\
\hline
\end{tabular}

Table 1: Descriptive statistics and data sources 


\begin{tabular}{|c|c|c|c|c|c|c|c|c|}
\hline Cross-section & & growth & $\log \left(g d p_{0}\right)$ & $\log \left(\operatorname{inv}_{30}\right)$ & $\log \left(\right.$ educ $\left._{0}\right)$ & $\operatorname{dem}_{30}$ & $\mathrm{ecO}_{30}$ & lat \\
\hline & growth & 1.00 & & & & & & \\
\hline & $\log \left(\operatorname{gdp}_{0}\right)$ & 0.04 & 1.00 & & & & & \\
\hline & $\log \left(\operatorname{inv}_{30}\right)$ & 0.51 & 0.56 & 1.00 & & & & \\
\hline & $\log \left(\right.$ educ $\left._{0}\right)$ & 0.34 & 0.73 & 0.56 & 1.00 & & & \\
\hline & $\operatorname{dem}_{30}$ & 0.22 & 0.74 & 0.47 & 0.64 & 1.00 & & \\
\hline & $\mathrm{ecO}_{30}$ & 0.44 & 0.57 & 0.48 & 0.54 & 0.56 & 1.00 & \\
\hline & lat & 0.24 & 0.67 & 0.42 & 0.53 & 0.55 & 0.43 & 1.00 \\
\hline$\overline{\text { Panel }}$ & & growth & 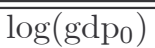 & $\overline{l o g}\left(\right.$ inv $\left._{5}\right)$ & $\overline{l o g}\left(\right.$ educ $\left._{0}\right)$ & 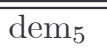 & $\mathrm{ecO}_{5}$ & lat \\
\hline & growth & 1.00 & & & & & & \\
\hline & $\log \left(\operatorname{gdp}_{0}\right)$ & 0.14 & 1.00 & & & & & \\
\hline & $\log \left(\operatorname{inv}_{5}\right)$ & 0.37 & 0.65 & 1.00 & & & & \\
\hline & $\log \left(\right.$ educ $\left._{0}\right)$ & 0.22 & 0.78 & 0.54 & 1.00 & & & \\
\hline & $\operatorname{dem}_{5}$ & 0.08 & 0.69 & 0.38 & 0.59 & 1.00 & & \\
\hline & $\mathrm{eCO}_{5}$ & 0.29 & 0.59 & 0.42 & 0.51 & 0.49 & 1.00 & \\
\hline & lat & 0.17 & 0.70 & 0.47 & 0.51 & 0.50 & 0.35 & 1.00 \\
\hline
\end{tabular}

Table 2: Correlations

\begin{tabular}{rrrr}
\hline Variable & & Mean & SD \\
\hline \hline $\operatorname{dem}_{5}$ & overall & 5.67 & 4.02 \\
& between & & 3.58 \\
& within & & 1.95 \\
\hline $\mathrm{ecO}_{5}$ & overall & 5.81 & 1.13 \\
& between & & 0.96 \\
& within & & 0.61 \\
\hline
\end{tabular}

Table 3: Decomposition into between-country and within-country components 


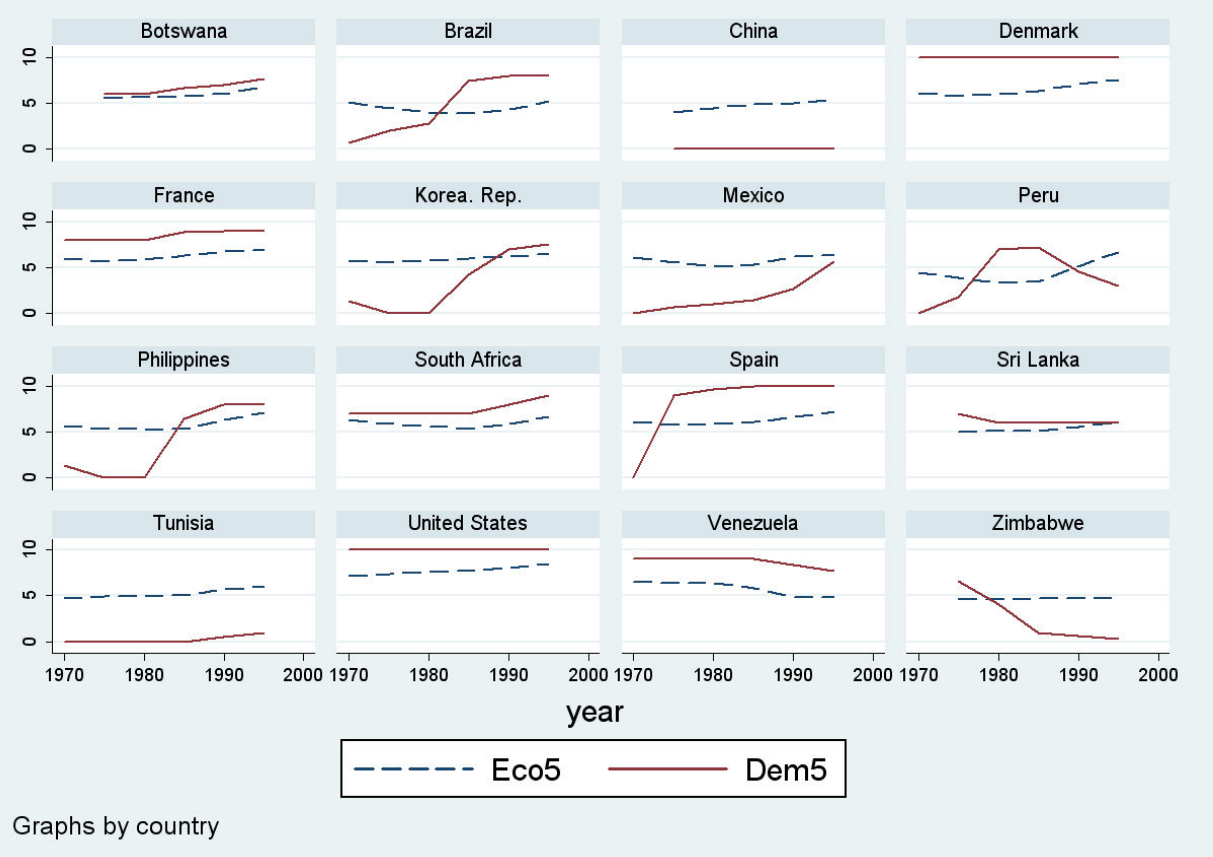

Figure 1: Institutions over time 


\begin{tabular}{|c|c|c|c|c|c|}
\hline Variable & OLS & $\begin{array}{c}\text { IV } \\
(\text { educ }) \\
\end{array}$ & $\begin{array}{l}\mathrm{IV} \\
(\mathrm{dem}) \\
\end{array}$ & $\begin{array}{l}\text { IV } \\
(\text { eco }) \\
\end{array}$ & $\begin{array}{c}\text { IV } \\
(\text { educ,dem,eco) } \\
\end{array}$ \\
\hline intercept & $\begin{array}{l}11.03^{* * *} \\
(4.11)\end{array}$ & $\begin{array}{l}14.99^{*} \\
(8.59)\end{array}$ & $\begin{array}{c}5.72 \\
(10.12)\end{array}$ & $\begin{array}{l}9.90 \\
(6.97)\end{array}$ & $\begin{array}{l}35.63 \\
(38.87)\end{array}$ \\
\hline $\log \left(g_{d p_{0}}\right)$ & $\begin{array}{l}-1.94^{* * *} \\
(0.28)\end{array}$ & $\begin{array}{l}-2.17^{* * *} \\
(0.65)\end{array}$ & $\begin{array}{l}-2.16^{* *} \\
(0.90)\end{array}$ & $\begin{array}{l}-1.45^{* * *} \\
(0.40)\end{array}$ & $\begin{array}{l}-2.64 \\
(2.52)\end{array}$ \\
\hline $\log ($ pop +0.05$)$ & $\begin{array}{c}-2.47 \\
(1.60)\end{array}$ & $\begin{array}{c}-2.79 \\
(3.45)\end{array}$ & $\begin{array}{l}0.95 \\
(5.95)\end{array}$ & $\begin{array}{c}-3.48 \\
(2.79)\end{array}$ & $\begin{array}{l}-7.89 \\
(19.44)\end{array}$ \\
\hline $\log \left(\operatorname{inv}_{30}\right)$ & $\begin{array}{l}1.87^{* * *} \\
(0.35)\end{array}$ & $\begin{array}{l}1.14^{* *} \\
(0.54)\end{array}$ & $\begin{array}{l}1.54^{* *} \\
(0.60)\end{array}$ & $\begin{array}{l}1.266^{* * *} \\
(0.457)\end{array}$ & $\begin{array}{c}1.04 \\
(1.86)\end{array}$ \\
\hline $\log \left(\right.$ educ $\left._{0}\right)$ & $\begin{array}{l}0.74^{* *} \\
(0.29)\end{array}$ & $\begin{array}{l}2.37^{* *} \\
(1.01)\end{array}$ & $\begin{array}{l}0.53^{*} \\
(0.55)\end{array}$ & $\begin{array}{l}0.79^{* *} \\
(0.37)\end{array}$ & $\begin{array}{l}5.86 \\
(5.76)\end{array}$ \\
\hline $\operatorname{dem}_{30}$ & $\begin{array}{l}\mathbf{0 . 0 5} \\
(0.06)\end{array}$ & $\begin{array}{c}-\mathbf{0 . 1 2} \\
(0.11)\end{array}$ & $\begin{array}{l}\mathbf{0 . 3 5} \\
(0.44)\end{array}$ & $\begin{array}{c}-\mathbf{0 . 0 6} \\
(0.08)\end{array}$ & $\begin{array}{c}-\mathbf{0 . 6 8} \\
(1.90)\end{array}$ \\
\hline $\mathrm{ecO}_{30}$ & $\begin{array}{l}\mathbf{0 . 7 5 ^ { * * * }} \\
(0.20)\end{array}$ & $\begin{array}{l}\mathbf{0 . 7 2}^{\text {*** }} \\
(0.33)\end{array}$ & $\begin{array}{l}\mathbf{0 . 8 1} \\
(0.34)\end{array}$ & $\begin{array}{l}\mathbf{1 . 0 5}^{\text {.0* }} \\
(0.42)\end{array}$ & $\begin{array}{c}-\mathbf{0 . 6 6} \\
(2.08)\end{array}$ \\
\hline lat & $\begin{array}{l}1.64 \\
(1.13) \\
\end{array}$ & $\begin{array}{l}1.08 \\
(2.15)\end{array}$ & $\begin{array}{l}1.42 \\
(2.59) \\
\end{array}$ & $\begin{array}{c}-0.05 \\
(1.69) \\
\end{array}$ & $\begin{array}{l}2.25 \\
(7.01) \\
\end{array}$ \\
\hline nobs & 73 & 43 & 43 & 43 & 43 \\
\hline$R^{2}$ & 0.62 & 0.47 & 0.37 & 0.58 & 0.15 \\
\hline Hausman test & & $<0.001$ & $<0.001$ & $<0.001$ & $<0.001$ \\
\hline Sargan test & & 0.13 & 0.057 & 0.003 & - \\
\hline Weak instr. & & 2.63 & 0.71 & 5.89 & - \\
\hline
\end{tabular}

Table 4: Cross-section: standard regression models. For IV estimation, settler mortality in logs, population density in 1500 (in logs) and French legal origin are used as instruments. For Hausman and Sargan tests, the $p$-values are reported. For weak instruments test, the value of the first-stage- $F$ statistic is reported. ${ }^{* * *}$ significant at $1 \%,{ }^{* *}$ significant at $5 \%,{ }^{*}$ significant at $10 \%$. 


\begin{tabular}{|c|c|c|c|c|}
\hline Variable & $\begin{array}{l}\text { Pooled } \\
\text { OLS } \\
\text { (i) }\end{array}$ & $\begin{array}{l}\text { Fixed- } \\
\text { Effects } \\
\text { (ii) }\end{array}$ & $\begin{array}{l}\text { Random- } \\
\text { Effects } \\
\text { (iii) }\end{array}$ & $\begin{array}{l}\text { IV-Fixed } \\
\text { Effects } \\
\text { (iv) }\end{array}$ \\
\hline intercept & $\begin{array}{l}5.79^{* *} \\
(2.80)\end{array}$ & - & $\begin{array}{l}8.14^{* *} \\
3.42\end{array}$ & - \\
\hline $\log \left(g_{d p}\right)$ & $\begin{array}{l}-1.28^{* * *} \\
(0.19)\end{array}$ & $\begin{array}{c}-5.63^{* * *} \\
(0.55)\end{array}$ & $\begin{array}{l}-1.70^{* * *} \\
(0.26)\end{array}$ & $\begin{array}{l}-4.76^{* * *} \\
(0.72)\end{array}$ \\
\hline $\log ($ pop +0.05$)$ & $\begin{array}{l}-3.33^{* * *} \\
(1.17)\end{array}$ & $\begin{array}{l}-3.69^{* *} \\
(1.75)\end{array}$ & $\begin{array}{l}-3.43^{* *} \\
(1.42)\end{array}$ & $\begin{array}{c}-0.82 \\
(2.04)\end{array}$ \\
\hline $\log \left(\right.$ inv $\left._{5}\right)$ & $\begin{array}{l}2.30^{* * *} \\
(0.31)\end{array}$ & $\underbrace{1.61^{* * *}}_{(0.50)}$ & ${\underset{(0.39)}{1.91}}^{\text {*** }}$ & $\begin{array}{l}0.90 \\
(0.61)\end{array}$ \\
\hline $\log \left(\right.$ educ $\left._{0}\right)$ & $\begin{array}{l}1.10^{* * * *} \\
(0.30)\end{array}$ & $\begin{array}{c}-1.48^{*} \\
(0.85)\end{array}$ & $\begin{array}{l}1.30^{* * *} \\
(0.42)\end{array}$ & $\begin{array}{c}-1.69 \\
(2.50)\end{array}$ \\
\hline $\operatorname{dem}_{5}$ & $\begin{array}{c}-\mathbf{0 . 0 6} \\
(0.04)\end{array}$ & $\begin{array}{c}-\mathbf{0 . 1 2}^{*} \\
(0.06)\end{array}$ & $\begin{array}{c}-\mathbf{0 . 0 4} \\
(0.05)\end{array}$ & $\begin{array}{l}\mathbf{0 . 1 0} \\
(0.16)\end{array}$ \\
\hline $\mathrm{eCO}_{5}$ & $\begin{array}{l}\mathbf{0 . 8 0} \mathbf{0}^{* * * *} \\
(0.14)\end{array}$ & $\underbrace{\mathbf{1 . 1 8}^{* * *}}_{(0.22)}$ & $\begin{array}{l}\mathbf{1 . 0 7}_{(0.18)}^{* * * *} \\
\text { (1) }\end{array}$ & $\begin{array}{l}\mathbf{1 . 3 0}_{(0.41)}^{* * *} \\
\end{array}$ \\
\hline lat & $\begin{array}{l}1.72^{*} \\
(0.96)\end{array}$ & - & $\begin{array}{l}3.36^{* *} \\
(1.46)\end{array}$ & - \\
\hline time dummies & $\ldots$ & $\ldots$ & $\ldots$ & $\ldots$ \\
\hline nobs & 406 & 406 & 406 & 331 \\
\hline ncountries & 74 & 74 & 74 & 74 \\
\hline$R^{2}$ & 0.30 & 0.37 & 0.26 & 0.35 \\
\hline $\begin{array}{l}\text { time-effects test } \\
\text { country-effects test }\end{array}$ & $<0.001$ & $\begin{array}{l}<0.001 \\
<0.001\end{array}$ & $<0.001$ & \\
\hline Hausman test & & & $\begin{array}{l}<0.001 \\
\text { (iii)-(ii) }\end{array}$ & $\begin{array}{l}0.002 \\
\text { (iv)-(ii) }\end{array}$ \\
\hline
\end{tabular}

Table 5: Panel data: standard regression models with time fixed-effects. For IV estimation, first lags of $\log \left(\right.$ educ $\left._{0}\right)$, dem $_{5}$ and eco ${ }_{5}$ are used as instruments. ${ }^{*}$ significant at $10 \%$, ${ }^{* *}$ significant at $5 \%,{ }^{* * *}$ significant at $1 \%$. The estimation results are obtained using $\mathrm{R}$ and the plm package. 


\begin{tabular}{|c|c|c|c|c|c|c|c|c|}
\hline$Z$ & - & dem & $\mathrm{eco}$ & lat & dem,eco & dem,lat & eco,lat & dem,eco,lat \\
\hline $\mathrm{K}=1$ & $\begin{array}{l}\mathbf{2 6 0 . 1} \\
{[239.4]}\end{array}$ & & & $X=\{\mathrm{d} \epsilon$ & n,eco,lat & & & \\
\hline $\mathrm{K}=2$ & $\begin{array}{l}257.4 \\
{[213.8]}\end{array}$ & $\begin{array}{l}263.1 \\
{[217.3]}\end{array}$ & $\begin{array}{l}271.2 \\
{[225.4]}\end{array}$ & $\begin{array}{l}251.4 \\
{[205.0]}\end{array}$ & $\begin{array}{l}267.3 \\
{[219.2]}\end{array}$ & $\begin{array}{l}255.9 \\
{[207.8]}\end{array}$ & $\begin{array}{l}252.4 \\
{[204.3]}\end{array}$ & $\begin{array}{l}257.3 \\
{[206.9]}\end{array}$ \\
\hline $\mathrm{K}=1$ & $\begin{array}{l}258.0 \\
{[239.6]}\end{array}$ & & & $X=\{$ & em,eco $\}$ & & & \\
\hline$K=2$ & $\begin{array}{l}249.4 \\
{[210.5]}\end{array}$ & $\begin{array}{l}265.5 \\
{[224.3]}\end{array}$ & $\begin{array}{l}252.0 \\
{[210.8]}\end{array}$ & $\begin{array}{l}249.2 \\
{[208.0]}\end{array}$ & $\begin{array}{l}263.6 \\
{[220.1]} \\
\end{array}$ & $\begin{array}{l}251.8 \\
{[208.9]}\end{array}$ & $\begin{array}{l}251.8 \\
{[208.3]} \\
\end{array}$ & $\begin{array}{l}256.1 \\
{[210.3]} \\
\end{array}$ \\
\hline $\mathrm{K}=1$ & $\begin{array}{l}256.4 \\
{[238.1]}\end{array}$ & & & $X=$ & co,lat $\}$ & & & \\
\hline $\mathrm{K}=2$ & $\begin{array}{l}249.6 \\
{[210.7]}\end{array}$ & $\begin{array}{l}241.7 \\
{[200.4]} \\
\end{array}$ & $\begin{array}{l}251.7 \\
{[210.5]}\end{array}$ & $\begin{array}{l}252.9 \\
{[211.7]}\end{array}$ & $\begin{array}{l}264.2 \\
{[220.7]}\end{array}$ & $\begin{array}{l}250.8 \\
{[207.3]}\end{array}$ & $\begin{array}{l}255.2 \\
{[211.7]}\end{array}$ & $\begin{array}{l}255.1 \\
{[209.3]}\end{array}$ \\
\hline $\mathrm{K}=1$ & $\begin{array}{l}254.1 \\
{[238.1]}\end{array}$ & & & & $\{\mathrm{eco}\}$ & & & \\
\hline$K=2$ & $\begin{array}{l}255.3 \\
{[221.0]}\end{array}$ & $\begin{array}{l}258.8 \\
{[222.3]}\end{array}$ & $\begin{array}{l}254.1 \\
{[217.5]}\end{array}$ & $\begin{array}{l}276.5 \\
{[246.7]}\end{array}$ & $\begin{array}{l}263.2 \\
{[224.2]}\end{array}$ & $\begin{array}{l}245.9 \\
{[207.0]}\end{array}$ & $\begin{array}{l}248.7 \\
{[209.7]}\end{array}$ & $\begin{array}{l}249.7 \\
{[208.5]}\end{array}$ \\
\hline $\mathrm{K}=1$ & $\begin{array}{l}265.1 \\
{[251.3]}\end{array}$ & & & & & & & \\
\hline$K=2$ & $\begin{array}{l}276.3 \\
{[246.5]}\end{array}$ & $\begin{array}{l}269.3 \\
{[237.2]}\end{array}$ & $\begin{array}{l}263.1 \\
{[231.0]}\end{array}$ & $\begin{array}{l}266.8 \\
{[234.7]}\end{array}$ & $\begin{array}{l}262.5 \\
{[228.1]}\end{array}$ & $\begin{array}{l}262.6 \\
{[228.3]}\end{array}$ & $\begin{array}{l}264.8 \\
{[230.4]}\end{array}$ & $\begin{array}{l}266.3 \\
{[229.7]}\end{array}$ \\
\hline
\end{tabular}

Table 6: Cross-section: selection of mixture models with BIC criterion (AIC in brackets). $Z$ is the set of concomitant variables included in the finite mixture model, $X$ is the set of additional standard covariates. The selected model is framed. Estimation results obtained using $R$ and the flexmix package.

\begin{tabular}{|c|c|c|c|c|}
\hline \multirow[t]{2}{*}{ Variable } & \multicolumn{2}{|c|}{ Mixture } & \multicolumn{2}{|c|}{ Wald test } \\
\hline & $\underset{(30 \%)}{\operatorname{group}} 1$ & $\underset{(70 \%)}{\operatorname{group}} 2$ & statistic & $p$-value \\
\hline intercept & $\begin{array}{l}17.89^{* * *} \\
(1.18)\end{array}$ & $\begin{array}{l}12.96^{* * *} \\
(4.42)\end{array}$ & 1.16 & 0.28 \\
\hline $\log \left(\operatorname{gdp}_{0}\right)$ & $\begin{array}{l}-2.29^{* * *} \\
(0.08)\end{array}$ & $\begin{array}{l}-1.95^{* * *} \\
(0.29)\end{array}$ & 7.80 & 0.005 \\
\hline $\log (p o p+0.05)$ & $\begin{array}{l}-1.06^{* * *} \\
(0.29)\end{array}$ & $\begin{array}{l}-3.99^{* *} \\
(1.75)\end{array}$ & 2.39 & 0.12 \\
\hline $\log \left(\right.$ inv30 $_{30}$ & $\begin{array}{l}1.89^{* * *} \\
(0.13)\end{array}$ & $\begin{array}{l}1.47^{* * *} \\
(0.36)\end{array}$ & 1.20 & 0.27 \\
\hline $\log \left(\right.$ educ $\left._{0}\right)$ & $\begin{array}{l}-0.05 \\
(0.15)\end{array}$ & $\begin{array}{l}0.68^{* *} \\
(0.28)\end{array}$ & 5.28 & 0.02 \\
\hline $\mathrm{ecO}_{30}$ & $\begin{array}{l}-\mathbf{0 . 1 0}^{* *} \\
(0.04)\end{array}$ & $\begin{array}{l}\mathbf{1 . 1 5} 5^{* * *} \\
(0.23)\end{array}$ & 28.67 & $<0.001$ \\
\hline lat & $\begin{array}{l}5.01^{* * *} \\
(0.26)\end{array}$ & $\begin{array}{l}2.24 \\
(1.41)\end{array}$ & 3.73 & 0.05 \\
\hline \multicolumn{5}{|c|}{ Concomitant variables } \\
\hline intercept & - & $\begin{array}{l}5.34^{* * *} \\
(1.58)\end{array}$ & & \\
\hline $\operatorname{dem}_{30}$ & - & $\begin{array}{l}-\mathbf{0 . 6 3}^{* * *} \\
(0.19)\end{array}$ & & \\
\hline
\end{tabular}

Table 7: Cross-section: estimation results of the selected mixture model in Table 6, with 73 observations. ${ }^{* * *}$ significant at $1 \%,{ }^{* *}$ significant at $5 \%,{ }^{*}$ significant at $10 \%$. 


\begin{tabular}{|c|c|c|c|c|c|c|c|c|}
\hline $\mathrm{Z}$ & - & dem & eco & lat & dem,eco & dem,lat & eco,lat & dem,eco,lat \\
\hline $\mathrm{K}=1$ & $\begin{array}{c}\mathbf{1 9 1 6 . 2} \\
{[1930.2]}\end{array}$ & \multicolumn{5}{|c|}{$\mathrm{X}=\{$ dem,eco,lat $\}$} & & \\
\hline $\mathrm{K}=2$ & $\begin{array}{l}1860.4 \\
{[1889.4]}\end{array}$ & $\begin{array}{l}1844.3 \\
{[1874.3]}\end{array}$ & $\begin{array}{l}1847.5 \\
{[1877.5]}\end{array}$ & $\begin{array}{l}1835.5 \\
{[1865.5]}\end{array}$ & $\begin{array}{l}1842.7 \\
{[1873.7]}\end{array}$ & $\begin{array}{l}1834.3 \\
{[1865.3]}\end{array}$ & $\begin{array}{l}1835.1 \\
{[1866.1]}\end{array}$ & $\begin{array}{l}1837.2 \\
{[1869.2]}\end{array}$ \\
\hline$K=3$ & $\begin{array}{l}1861.6 \\
{[1905.6]}\end{array}$ & $\begin{array}{l}1848.5 \\
{[1894.5]}\end{array}$ & $\begin{array}{l}1852.1 \\
{[1898.1]}\end{array}$ & $\begin{array}{l}1840.3 \\
{[1886.4]}\end{array}$ & $\begin{array}{l}1851.9 \\
{[1899.9]}\end{array}$ & $\begin{array}{l}1836.6 \\
{[1884.6]}\end{array}$ & $\begin{array}{l}1836.7 \\
{[1884.7]}\end{array}$ & $\begin{array}{l}1842.3 \\
{[1892.3]}\end{array}$ \\
\hline $\mathrm{K}=1$ & $\begin{array}{l}1915.4 \\
{[1928.4]}\end{array}$ & \multicolumn{5}{|c|}{$\mathrm{X}=\{$ dem, $\mathrm{eco}\}$} & & \\
\hline$K=2$ & $\begin{array}{l}1856.2 \\
{[1883.2]}\end{array}$ & $\begin{array}{l}1838.6 \\
{[1866.6]}\end{array}$ & $\begin{array}{l}1843.0 \\
{[1871.0]}\end{array}$ & $\begin{array}{l}1838.8 \\
{[1866.8]}\end{array}$ & $\begin{array}{l}1843.8 \\
{[1862.8]}\end{array}$ & $\begin{array}{l}1840.4 \\
{[1859.4]}\end{array}$ & $\begin{array}{l}1842.4 \\
{[1861.4]}\end{array}$ & $\begin{array}{l}1844.6 \\
{[1864.6]}\end{array}$ \\
\hline $\mathrm{K}=3$ & $\begin{array}{l}1860.3 \\
{[1901.3]}\end{array}$ & $\begin{array}{l}1848.6 \\
{[1891.6]}\end{array}$ & $\begin{array}{l}1847.4 \\
{[1890.4]}\end{array}$ & $\begin{array}{l}1844.2 \\
{[1887.2]}\end{array}$ & $\begin{array}{l}1850.9 \\
{[1880.9]}\end{array}$ & $\begin{array}{l}1844.1 \\
{[1874.1]} \\
\end{array}$ & $\begin{array}{l}1850.9 \\
{[1880.9]}\end{array}$ & $\begin{array}{l}1852.4 \\
{[1884.4]}\end{array}$ \\
\hline $\mathrm{K}=1$ & $\begin{array}{l}1921.6 \\
{[1934.6]}\end{array}$ & \multicolumn{5}{|c|}{$\mathrm{X}=\{$ eco,lat $\}$} & & \\
\hline $\mathrm{K}=2$ & $\begin{array}{l}1869.5 \\
{[1896.5]}\end{array}$ & $\begin{array}{l}1846.8 \\
{[1874.8]}\end{array}$ & $\begin{array}{l}1855.2 \\
{[1883.2]}\end{array}$ & $\begin{array}{l}1838.2 \\
{[1866.2]}\end{array}$ & $\begin{array}{l}1848.9 \\
{[1877.9]}\end{array}$ & $\begin{array}{l}1837.0 \\
{[1866.0]}\end{array}$ & $\begin{array}{l}1837.9 \\
{[1866.9]}\end{array}$ & $\begin{array}{l}1840.0 \\
{[1870.0]}\end{array}$ \\
\hline $\mathrm{K}=3$ & $\begin{array}{l}1876.7 \\
{[1917.7]} \\
\end{array}$ & $\begin{array}{l}1853.6 \\
{[1896.6]} \\
\end{array}$ & $\begin{array}{l}1864.6 \\
{[1907.6]} \\
\end{array}$ & $\begin{array}{l}1844.5 \\
{[1887.5]} \\
\end{array}$ & $\begin{array}{l}1857.3 \\
{[1902.3]} \\
\end{array}$ & $\begin{array}{l}1844.1 \\
{[1889.1]} \\
\end{array}$ & $\begin{array}{l}1844.1 \\
{[1889.1]}\end{array}$ & $\begin{array}{l}1848.9 \\
{[1895.9]}\end{array}$ \\
\hline$K=1$ & $\begin{array}{l}1921.2 \\
{[1933.2]}\end{array}$ & \multicolumn{5}{|c|}{$\mathrm{X}=\{\mathrm{eco}\}$} & & \\
\hline $\mathrm{K}=2$ & $\begin{array}{l}1868.7 \\
{[1893.7]}\end{array}$ & $\begin{array}{l}1847.9 \\
{[1873.9]}\end{array}$ & $\begin{array}{l}1853.9 \\
{[1879.9]}\end{array}$ & $\begin{array}{l}1842.4 \\
{[1868.4]}\end{array}$ & $\begin{array}{l}1849.6 \\
{[1876.6]}\end{array}$ & $\begin{array}{l}1840.2 \\
{[1867.2]}\end{array}$ & $\begin{array}{l}1840.9 \\
{[1867.9]}\end{array}$ & $\begin{array}{l}1842.9 \\
{[1870.9]}\end{array}$ \\
\hline $\mathrm{K}=3$ & $\begin{array}{l}1873.6 \\
{[1911.6]} \\
\end{array}$ & $\begin{array}{l}1850.2 \\
{[1890.2]} \\
\end{array}$ & $\begin{array}{l}1858.7 \\
{[1898.7]} \\
\end{array}$ & $\begin{array}{l}1842.8 \\
{[1882.8]} \\
\end{array}$ & $\begin{array}{l}1853.7 \\
{[1895.7]} \\
\end{array}$ & $\begin{array}{l}1841.4 \\
{[1883.4]} \\
\end{array}$ & $\begin{array}{l}1841.7 \\
{[1883.7]} \\
\end{array}$ & $\begin{array}{l}1846.4 \\
{[1890.4]} \\
\end{array}$ \\
\hline $\mathrm{K}=1$ & $\begin{array}{l}2038.7 \\
{[2049.7]}\end{array}$ & \multicolumn{5}{|c|}{$\mathrm{X}=\{-\}$} & & \\
\hline $\mathrm{K}=2$ & $\begin{array}{l}1998.7 \\
{[2021.7]}\end{array}$ & $\begin{array}{l}1974.2 \\
{[1998.2]}\end{array}$ & $\begin{array}{l}1977.8 \\
{[2001.8]}\end{array}$ & $\begin{array}{l}1971.1 \\
{[1995.1]}\end{array}$ & $\begin{array}{l}1977.9 \\
{[2002.9]}\end{array}$ & $\begin{array}{l}1970.9 \\
{[1995.9]}\end{array}$ & $\begin{array}{l}1967.2 \\
{[1992.2]}\end{array}$ & $\begin{array}{l}1971.4 \\
{[1997.4]}\end{array}$ \\
\hline $\mathrm{K}=3$ & $\begin{array}{l}1995.9 \\
{[2030.9]}\end{array}$ & $\begin{array}{l}1967.8 \\
{[2004.8]}\end{array}$ & $\begin{array}{l}1971.4 \\
{[2008.4]}\end{array}$ & $\begin{array}{l}1964.3 \\
{[2001.3]}\end{array}$ & $\begin{array}{l}1965.9 \\
{[2004.9]}\end{array}$ & $\begin{array}{l}1972.3 \\
{[2011.3]}\end{array}$ & $\begin{array}{l}1958.6 \\
{[1997.6]}\end{array}$ & $\begin{array}{l}1964.8 \\
{[2005.8]}\end{array}$ \\
\hline
\end{tabular}

Table 8: Panel data: selection of mixture models with BIC criterion (AIC in brackets). $Z$ is the set of concomitant variables included in the finite mixture model, $X$ is the set of additional standard covariates. Selected model is framed. Estimation results obtained using Latent Gold. 


\begin{tabular}{|c|c|c|c|c|}
\hline \multirow[t]{2}{*}{ Variable } & \multicolumn{2}{|c|}{ Mixture } & \multicolumn{2}{|c|}{ Wald test } \\
\hline & $\underset{(28 \%)}{\operatorname{group}} 1$ & $\begin{array}{c}\text { group } \\
(72 \%)\end{array}$ & statistic & $p$-value \\
\hline intercept & $\begin{array}{c}-1.142 \\
(3.042)\end{array}$ & $\begin{array}{l}9.719^{* * *} \\
(3.543)\end{array}$ & 5.63 & 0.02 \\
\hline $\log \left(\operatorname{gdp}_{0}\right)$ & $\begin{array}{l}-0.749^{* *} \\
(0.328)\end{array}$ & $\begin{array}{l}-1.169^{* * *} \\
(0.224)\end{array}$ & 1.14 & 0.28 \\
\hline $\log ($ pop +0.05$)$ & $\begin{array}{l}3.500^{* * *} \\
(0.972)\end{array}$ & $\begin{array}{l}-6.914^{* * *} \\
(1.568)\end{array}$ & 35.55 & $<0.001$ \\
\hline $\log \left(\operatorname{inv}_{5}\right)$ & $\begin{array}{l}1.675^{* * *} \\
(0.488)\end{array}$ & $\begin{array}{l}2.328^{* * *} \\
(0.364)\end{array}$ & 1.12 & 0.29 \\
\hline $\log \left(\right.$ educ $\left._{0}\right)$ & $\begin{array}{l}-1.668^{* * *} \\
(0.470)\end{array}$ & $\begin{array}{l}0.922^{* * *} \\
(0.349)\end{array}$ & 19.9 & $<0.001$ \\
\hline $\operatorname{dem}_{5}$ & $\begin{array}{c}-\mathbf{0 . 0 1 4} \\
(0.055)\end{array}$ & $\begin{array}{l}-\mathbf{0 . 0 9 2}^{*} \\
(0.054)\end{array}$ & 1.03 & 0.31 \\
\hline $\mathrm{ecO}_{5}$ & $\underset{(0.147)}{\mathbf{0 . 3 4 6}}$ & ${\underset{(0.174)}{1.046 * *}}^{\text {1.** }}$ & 9.59 & 0.002 \\
\hline lat & $\begin{array}{l}2.364^{* *} \\
(1.014)\end{array}$ & $\begin{array}{l}3.042^{* *} \\
(1.304)\end{array}$ & 0.17 & 0.68 \\
\hline time dummies & $\ldots$ & $\ldots$ & & \\
\hline $\begin{array}{l}\text { Concomitant variables } \\
\text { intercept }\end{array}$ & - & $\begin{array}{l}5.91^{* * *} \\
(1.51)\end{array}$ & & \\
\hline $\operatorname{dem}_{30}$ & - & $\begin{array}{l}-\mathbf{0 . 2 9 9}^{* *} \\
(0.147)\end{array}$ & & \\
\hline lat & - & $\begin{array}{l}-9.603^{* * *} \\
(3.645)\end{array}$ & & \\
\hline$R^{2}$ & 0.54 & 0.39 & & \\
\hline
\end{tabular}

Table 9: Panel data: estimation results of the selected mixture model in Table 8, with time dummies, 406 observations. ${ }^{* * *}$ significant at 1\%, ** significant at 5\%, * significant at $10 \%$. 


\begin{tabular}{|c|c|c|c|}
\hline \multicolumn{2}{|l|}{ Group 1} & \multicolumn{2}{|l|}{ Group 2} \\
\hline Country & proba & Country & proba \\
\hline Australia & 0.99 & "Algeria & $\begin{array}{ll}1 \\
1\end{array}$ \\
\hline Austria & 0.99 & Argentina & 1 \\
\hline Belgium & 1 & Bangladesh & 1 \\
\hline Botswana & 1 & Bolivia & 1 \\
\hline Canada & 1 & Brazil & 1 \\
\hline Denmark & 0.99 & Chile & 1 \\
\hline Egypt & 0.99 & China & 1 \\
\hline Finland & 0.99 & Colombia & 0.99 \\
\hline France & 0.99 & Costa Rica & 1 \\
\hline Greece & 0.98 & Cyprus & 1 \\
\hline Hungary & 0.99 & Dominican, Rep & 1 \\
\hline Israel & 0.99 & Ecuador & 1 \\
\hline Italy & 0.99 & El Salvador & 1 \\
\hline Japan & 0.99 & Ghana & 1 \\
\hline Netherlands & 1 & Guatemala & 1 \\
\hline New Zealand & 0.99 & Guinea-Bissau & 1 \\
\hline Norway & 0.99 & Honduras & 1 \\
\hline Portugal & 0.89 & India & 1 \\
\hline Spain & 0.96 & Indonesia & 0.99 \\
\hline Sweden & 1 & Iran & 1 \\
\hline Switzerland & 1 & Ireland & 1 \\
\hline United Kingdom & 0.99 & Jamaica & 1 \\
\hline United States & 0.99 & Jordan & 1 \\
\hline & & Kenya & 1 \\
\hline & & Korea. Rep. & 1 \\
\hline & & Malaysia & 0.99 \\
\hline & & Mali & 1 \\
\hline & & Mexico & 0.99 \\
\hline & & Nicaragua & 1 \\
\hline & & Niger & 1 \\
\hline & & Panama & 1 \\
\hline & & Papua New Guinea & 1 \\
\hline & & Paraguay & 1 \\
\hline & & Peru & 1 \\
\hline & & Philippines & 1 \\
\hline & & Poland & 0.56 \\
\hline & & Senegal & 1 \\
\hline & & Sierra Leone & 1 \\
\hline & & Singapore & 0.99 \\
\hline & & South Africa & 1 \\
\hline & & Sri Lanka & 0.86 \\
\hline & & Tanzania & 1 \\
\hline & & Thailand & 1 \\
\hline & & Trinidad and Tobago & 1 \\
\hline & & Tunisia & 1 \\
\hline & & Turkey & 1 \\
\hline & & Uganda & 0.85 \\
\hline & & Uruguay & 1 \\
\hline & & Venezuela & 1 \\
\hline & & Zambia & 1 \\
\hline & & Zimbabwe & 1 \\
\hline
\end{tabular}

Table 10: Panel data: classification obtained from the selected mixture model with group membership posterior probabilities 


\begin{tabular}{lcc}
\hline & Group 1 & Group 2 \\
\hline \hline growth & 2.287 & 1.425 \\
& $(1.558)$ & $(3.238)$ \\
eco5 & 6.483 & 5.459 \\
& $(0.987)$ & $(1.038)$ \\
dem $_{5}$ & 8.929 & 4.247 \\
& $(2.679)$ & $(3.628)$ \\
lat & 0.501 & 0.203 \\
& $(0.127)$ & $(0.137)$ \\
\hline
\end{tabular}

Table 11: Means of variables by groups, from the classification obtained in Table 10 (standard deviations in parenthesis).

\begin{tabular}{lcc}
\hline Variable & $\begin{array}{c}\text { 2SLS } \\
\text { Group } 1 \\
(28 \%)\end{array}$ & $\begin{array}{c}\text { 2SLS } \\
\text { Group } 2 \\
(72 \%)\end{array}$ \\
\hline \hline intercept & 1.413 & $9.244^{* * *}$ \\
& $(3.514)$ & $(3.449)$ \\
$\log \left(\mathrm{gdp}_{0}\right)$ & $-0.907^{* *}$ & $-1.416^{* * *}$ \\
& $(0.377)$ & $(0.230)$ \\
$\log ($ pop +0.05$)$ & $3.709^{* * *}$ & $-6.523^{* * *}$ \\
& $(1.242)$ & $(1.524)$ \\
$\log \left(\right.$ inv $\left._{5}\right)$ & 0.339 & $2.466^{* * *}$ \\
$\log \left(\right.$ educ $\left._{0}\right)$ & $(0.753)$ & $(0.357)$ \\
& $-1.523^{* * *}$ & $1.088^{* * *}$ \\
$\operatorname{dem} 5$ & $(0.569)$ & $(0.374)$ \\
& $0.324^{* *}$ & 0.029 \\
eco5 & $(0.146)$ & $(0.0639)$ \\
$\operatorname{lat}$ & 0.276 & $0.956^{* * *}$ \\
& $(0.191)$ & $(0.202)$ \\
time dummies & 1.771 & $4.100^{* * *}$ \\
\hline nobs & $(1.237)$ & $(1.249)$ \\
ncountries & $\ldots$ & $\ldots$ \\
Hausman test & $<0.001$ & 219 \\
Weak instr. & 20.57 & 140.98 \\
\hline
\end{tabular}

Table 12: IV estimations by groups, from the classification obtained in Table 10 (standard errors in parenthesis). First lags of $\log \left(\right.$ educ $\left._{0}\right)$, dem $_{5}$ and eco $_{5}$ are used as instruments. For Hausman test, the $p$-values are reported. For weak instruments test, the value of the first-stage- $F$ statistic is reported. ${ }^{* * *}$ significant at $1 \%,{ }^{* *}$ significant at $5 \%,{ }^{*}$ significant at $10 \%$. 


\begin{tabular}{|c|c|c|c|c|c|c|}
\hline \multirow[t]{2}{*}{ Variable } & \multicolumn{2}{|c|}{ (i) } & \multicolumn{2}{|c|}{ (ii) } & \multicolumn{2}{|c|}{ (iii) } \\
\hline & $\begin{array}{c}\text { group } 1 \\
(31 \%) \\
\end{array}$ & $\begin{array}{c}\text { group } 2 \\
(69 \%) \\
\end{array}$ & $\begin{array}{c}\text { group } 1 \\
(34 \%) \\
\end{array}$ & $\begin{array}{c}\text { group } 2 \\
(66 \%)\end{array}$ & $\begin{array}{c}\text { group } 1 \\
(46 \%) \\
\end{array}$ & $\begin{array}{c}\text { group } 2 \\
(54 \%) \\
\end{array}$ \\
\hline Intercept & $\begin{array}{c}-5.153^{* *} \\
(2.592)\end{array}$ & $\begin{array}{l}5.475 \\
(3.952)\end{array}$ & $\begin{array}{c}-5.025^{*} \\
(2.578)\end{array}$ & $\begin{array}{l}5.146 \\
(3.983)\end{array}$ & $\begin{array}{c}-1.254 \\
(2.352)\end{array}$ & $\begin{array}{l}9.259^{* * *} \\
(3.556)\end{array}$ \\
\hline $\log \left(\operatorname{gdp}_{0}\right)$ & $\begin{array}{l}0.244 \\
(0.243)\end{array}$ & ${ }_{(0.241)}^{-1.181^{* * *}}$ & $\begin{array}{l}0.248 \\
(0.237)\end{array}$ & $\begin{array}{l}-1.209^{* * *} \\
(0.242)\end{array}$ & $\begin{array}{c}-0.680^{* * *} \\
(0.239)\end{array}$ & $\frac{-1.136^{* * *}}{(0.226)}$ \\
\hline $\log (\mathrm{pop}+0.05)$ & $\begin{array}{l}0.321 \\
(1.027)\end{array}$ & $\begin{array}{c}-4.107^{* *} \\
(1.673)\end{array}$ & $\begin{array}{l}0.297 \\
(1.039)\end{array}$ & $\begin{array}{c}-4.078^{* *} \\
(1.685)\end{array}$ & $\begin{array}{l}3.532^{* * *} \\
(0.902)\end{array}$ & $\begin{array}{c}-7.025^{* * *} \\
(1.565)\end{array}$ \\
\hline $\log \left(\operatorname{inv}_{5}\right)$ & $\begin{array}{l}1.809^{* * *} \\
(0.471)\end{array}$ & $\begin{array}{l}2.49 \\
(0.396)\end{array}$ & $\begin{array}{l}1.756^{* * *} \\
(0.447)\end{array}$ & $\begin{array}{l}2.523^{* * *} \\
(0.399)\end{array}$ & $\begin{array}{l}1.541^{* * *} \\
(0.423)\end{array}$ & $\begin{array}{l}2.501^{* * *} \\
(0.361)\end{array}$ \\
\hline $\log \left(\right.$ educ $\left._{0}\right)$ & $\begin{array}{c}-0.468 \\
(0.449)\end{array}$ & $\begin{array}{l}0.655 \\
(0.437)\end{array}$ & $\begin{array}{c}-0.455 \\
(0.433)\end{array}$ & $\begin{array}{l}0.732^{*} \\
(0.443)\end{array}$ & $\begin{array}{c}-1.725^{* * *} \\
(0.395)\end{array}$ & $\begin{array}{l}0.789^{* *} \\
(0.350)\end{array}$ \\
\hline $\operatorname{dem}_{5}$ & & & & & $\begin{array}{c}-0.016 \\
(0.052)\end{array}$ & $\begin{array}{c}-0.081 \\
(0.054)\end{array}$ \\
\hline $\mathrm{eCO}_{5}$ & & & & & $\begin{array}{l}0.346^{* *} \\
(0.141)\end{array}$ & $\begin{array}{l}1.049^{* * *} \\
(0.173)\end{array}$ \\
\hline xconst $_{5}$ & $\begin{array}{c}-0.122 \\
(0.104)\end{array}$ & $\begin{array}{c}-0.156 \\
(0.105)\end{array}$ & $\begin{array}{c}-0.117 \\
(0.102)\end{array}$ & $\begin{array}{c}-0.164 \\
(0.106)\end{array}$ & & \\
\hline $\mathrm{reg}_{5}$ & $\begin{array}{l}0.025 \\
(0.112)\end{array}$ & $\begin{array}{l}0.965^{* * *} \\
(0.213)\end{array}$ & $\begin{array}{l}0.021 \\
(0.111)\end{array}$ & $\begin{array}{l}1.015^{* * *} \\
(0.218)\end{array}$ & & \\
\hline lat & $\begin{array}{l}1.403 \\
(0.984)\end{array}$ & $\begin{array}{l}4.398^{* * *} \\
(1.416)\end{array}$ & $\begin{array}{l}1.395 \\
(0.985)\end{array}$ & $\begin{array}{l}4.396^{* * *} \\
(1.423)\end{array}$ & $\begin{array}{l}2.142^{* *} \\
(0.975)\end{array}$ & $\begin{array}{l}3.194^{* *} \\
(1.299)\end{array}$ \\
\hline time dummies & $\ldots$ & $\ldots$ & $\ldots$ & $\ldots$ & $\ldots$ & $\ldots$ \\
\hline \multicolumn{7}{|c|}{ Concomitant variables } \\
\hline Intercept & & $\begin{array}{l}7.326^{* * *} \\
(2.482)\end{array}$ & & $\begin{array}{l}6.635^{* * *} \\
(1.777)\end{array}$ & & $\begin{array}{l}3.226^{* *} \\
(1.354)\end{array}$ \\
\hline $\operatorname{dem}_{30}$ & & & & & & $\begin{array}{c}-0.388^{* *} \\
(0.186)\end{array}$ \\
\hline xconst $_{30}$ & & $\begin{array}{c}-0.728^{* *} \\
(0.335)\end{array}$ & & $\begin{array}{c}-0.751^{* *} \\
(0.296)\end{array}$ & & \\
\hline lat & & $\begin{array}{l}-8.104^{* * *} \\
(2.925)\end{array}$ & & $\begin{array}{c}-9.076^{* * *} \\
(3.223)\end{array}$ & & $\begin{array}{l}1.055 \\
(4.378)\end{array}$ \\
\hline $\log \left(\right.$ educ $\left._{70}\right)$ & & & & $\begin{array}{l}0.712 \\
(0.786)\end{array}$ & & \\
\hline landlocked & & & & & & $\begin{array}{c}-3.751 \\
(2.569)\end{array}$ \\
\hline OECD & & & & & & $\begin{array}{c}-1.898 \\
(1.499)\end{array}$ \\
\hline Latin Am & & & & & & $\begin{array}{l}5.139 \\
(3.229)\end{array}$ \\
\hline Africa & & & & & & $\begin{array}{l}2.134 \\
(2.626)\end{array}$ \\
\hline$R^{2}$ & 0.48 & 0.35 & 0.51 & 0.34 & 0.53 & 0.41 \\
\hline
\end{tabular}

Table 13: Panel data: estimation results of the selected models for the robustness $* * *$ significant at $1 \%,{ }^{* *}$ significant at $5 \%,{ }^{*}$ significant at $10 \%$. Due to some missing data for the measure of regulation (reg5) the number of observations falls to 362 observations in columns (i) and (ii), but the number of countries does not change 


\begin{tabular}{|c|c|c|c|c|}
\hline \multirow[t]{2}{*}{ Variable } & \multicolumn{2}{|c|}{ Period 1970-1985 } & \multicolumn{2}{|c|}{ Period 1985-2000 } \\
\hline & $\underset{(34 \%)}{\operatorname{group}} 1$ & $\underset{(66 \%)}{\operatorname{group}} 2$ & $\underset{(30 \%)}{\operatorname{group}} 1$ & $\underset{(70 \%)}{\operatorname{group}} 2$ \\
\hline Intercept & $\begin{array}{c}-7.517 \\
4.821)\end{array}$ & $\begin{array}{l}12.695^{*} \\
(6.623)\end{array}$ & $\begin{array}{c}-1.886 \\
(3.544)\end{array}$ & $\begin{array}{l}9.098^{* *} \\
(4.121)\end{array}$ \\
\hline $\log \left(\operatorname{gdp}_{0}\right)$ & $\begin{array}{c}-0.902^{* *} \\
(0.406)\end{array}$ & $\begin{array}{c}-1.366^{* * *} \\
(0.379)\end{array}$ & $\begin{array}{l}0.089 \\
(0.420)\end{array}$ & $\begin{array}{l}-1.072^{* * *} \\
(0.296)\end{array}$ \\
\hline $\log (\mathrm{pop}+0.05)$ & $\begin{array}{l}4.438^{* * *} \\
(1.409)\end{array}$ & $\begin{array}{l}-7.808^{* *} \\
(3.039)\end{array}$ & $\begin{array}{l}4.922^{* *} \\
(1.548)\end{array}$ & $\begin{array}{l}-7.081^{* * *} \\
(1.798)\end{array}$ \\
\hline $\log \left(\right.$ inv $\left._{5}\right)$ & $\begin{array}{l}2.432^{* * *} \\
(0.763)\end{array}$ & $\begin{array}{l}2.491^{* * *} \\
(0.643)\end{array}$ & $\begin{array}{c}-0.187 \\
(0.967)\end{array}$ & $\begin{array}{l}1.875^{\text {*** }} \\
(0.410)\end{array}$ \\
\hline $\log \left(\right.$ educ $\left._{0}\right)$ & $\begin{array}{c}-0.722 \\
(0.482)\end{array}$ & $\begin{array}{l}1.223^{* *} \\
(0.579)\end{array}$ & $\begin{array}{l}-3.510^{* * *} \\
(0.812)\end{array}$ & $\begin{array}{l}0.709 \\
(0.455)\end{array}$ \\
\hline $\operatorname{dem}_{5}$ & $\begin{array}{l}-0.137^{* *} \\
(0.062)\end{array}$ & $\begin{array}{c}-0.108 \\
(0.096)\end{array}$ & $\begin{array}{c}-0.036 \\
(0.161)\end{array}$ & $\begin{array}{c}-0.111 \\
(0.068)\end{array}$ \\
\hline $\mathrm{ecO}_{5}$ & $\begin{array}{l}0.553^{* * *} \\
(0.165)\end{array}$ & $\begin{array}{l}0.966^{\text {*** }} \\
(0.327)\end{array}$ & $\begin{array}{l}0.415^{*} \\
(0.233)\end{array}$ & $\begin{array}{l}1.301^{\text {*** }} \\
(0.213)\end{array}$ \\
\hline lat & $\begin{array}{l}3.561^{* * *} \\
(1.295)\end{array}$ & $\begin{array}{l}0.773 \\
(2.860)\end{array}$ & $\begin{array}{l}1.654 \\
(1.505)\end{array}$ & $\begin{array}{l}3.712^{* *} \\
(1.502)\end{array}$ \\
\hline time dummies & $\ldots$ & $\ldots$ & $\ldots$ & $\ldots$ \\
\hline \multicolumn{5}{|c|}{ Concomitant variables } \\
\hline Intercept & & $\begin{array}{l}6.805^{* * *} \\
(2.478)\end{array}$ & & $\begin{array}{l}9.202^{* * *} \\
(2.861)\end{array}$ \\
\hline $\operatorname{dem}_{15}$ & & $\begin{array}{c}-0.254^{* *} \\
(0.122)\end{array}$ & & $\begin{array}{l}-0.705^{* *} \\
(0.329)\end{array}$ \\
\hline lat & & $\begin{array}{c}-15.270^{* *} \\
(6.489)\end{array}$ & & $\begin{array}{l}-7.753^{* *} \\
(3.111)\end{array}$ \\
\hline$R^{2}$ & 0.64 & 0.31 & 0.52 & 0.46 \\
\hline
\end{tabular}

Table 14: Panel data: estimation results of the selected mixture model by subsamples. There are 71 countries with 190 observations for the first subsample, and 74 countries with 216 observations for the second subsample. ${ }^{* *}$ significant at $1 \%,{ }^{* *}$ significant at $5 \%,{ }^{*}$ significant at $10 \%$. 